\title{
Modeling anthropogenically controlled secondary organic aerosols in a megacity: a simplified framework for global and climate models
}

\author{
A. Hodzic ${ }^{1}$ and J. L. Jimenez ${ }^{2}$ \\ ${ }^{1}$ National Center for Atmospheric Research, Boulder, CO, USA \\ ${ }^{2}$ Dept. of Chemistry and Biochemistry, and CIRES, University of Colorado, Boulder, CO, USA
}

Received: 18 March 2011 - Published in Geosci. Model Dev. Discuss.: 19 April 2011

Revised: 29 September 2011 - Accepted: 12 October 2011 - Published: 24 October 2011

\begin{abstract}
A simplified parameterization for secondary organic aerosol (SOA) formation in polluted air and biomass burning smoke is tested and optimized in this work, towards the goal of a computationally inexpensive method to calculate pollution and biomass burning SOA mass and hygroscopicity in global and climate models. A regional chemistry-transport model is used as the testbed for the parameterization, which is compared against observations from the Mexico City metropolitan area during the MILAGRO 2006 field experiment. The empirical parameterization is based on the observed proportionality of SOA concentrations to excess $\mathrm{CO}$ and photochemical age of the airmass. The approach consists in emitting an organic gas as lumped SOA precursor surrogate proportional to anthropogenic or biomass burning $\mathrm{CO}$ emissions according to the observed ratio between $\mathrm{SOA}$ and $\mathrm{CO}$ in aged air, and reacting this surrogate with $\mathrm{OH}$ into a single non-volatile species that condenses to form SOA. An emission factor of $0.08 \mathrm{~g}$ of the lumped SOA precursor perg of $\mathrm{CO}$ and a rate constant with $\mathrm{OH}$ of $1.25 \times 10^{-11} \mathrm{~cm}^{3}$ molecule $\mathrm{e}^{-1} \mathrm{~s}^{-1}$ reproduce the observed average SOA mass within $30 \%$ in the urban area and downwind. When a 2.5 times slower rate is used $\left(5 \times 10^{-12} \mathrm{~cm}^{3}\right.$ molecule $\left.\mathrm{s}^{-1}\right)$ the predicted SOA amount and temporal evolution is nearly identical to the results obtained with SOA formation from semi-volatile and intermediate volatility primary organic vapors according to the Robinson et al. (2007) formulation. Our simplified method has the advantage of being much less computationally expensive than Robinson-type methods, and can be used in regions where the emissions of SOA precursors are not yet available. As the aged $\mathrm{SOA} / \triangle \mathrm{CO}$ ratios are rather consistent globally for anthropogenic pollution, this parameterization could be
\end{abstract}

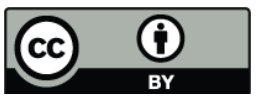

Correspondence to: A. Hodzic (alma@ucar.edu) reasonably tested in and applied to other regions. The evolution of oxygen-to-carbon ratio was also empirically modeled and the predicted levels were found to be in reasonable agreement with observations. The potential enhancement of biogenic SOA by anthropogenic pollution, which has been suggested to play a major role in global SOA formation, is also tested using two simple parameterizations. Our results suggest that the pollution enhancement of biogenic SOA could provide additional SOA, but does not however explain the concentrations or the spatial and temporal variations of measured SOA mass in the vicinity of Mexico City, which appears to be controlled by anthropogenic sources. The contribution of the biomass burning to the predicted SOA is less than $10 \%$ during the studied period.

\section{Introduction}

The representation of sources and formation processes of organic aerosols $(\mathrm{OA})$ in chemistry and climate models is currently highly uncertain. This leads to inaccurate estimates of OA mass and the radiative forcing associated with atmospheric aerosols (Kiehl, 2007), as well as the difficulty to distinguish between naturally and anthropogenically controlled OA (Carlton et al., 2010; Hoyle et al., 2011). Accurate predictions of OA mass and its sources are key to predicting aerosol evolution and radiative forcing under future climate and emission scenarios. OA is composed of a mixture of primary emitted organic matter (POA) and secondary organic aerosols (SOA) formed by gas-to-particle conversion. The spatio-temporal distribution of OA concentrations depends on their primary emission sources, atmospheric transport and mixing, chemical processing, and removal by deposition. While significant uncertainties exist at all levels of OA processing, the largest unknowns reside in the representation of the formation and ageing of SOA (Hallquist et al., 2009).

Published by Copernicus Publications on behalf of the European Geosciences Union. 
Comparisons with data from recently developed fast instrumentation have confirmed the tendency of models to greatly underpredict the levels of SOA formed in urban plumes when only the SOA formation from volatile organic compounds (VOCs) is considered (e.g. de Gouw et al., 2005; Dzepina et al., 2009; Hodzic et al., 2009; Shrivastava et al., 2010; Lee-Taylor et al., 2011). Hodzic et al. (2009) estimated the missing SOA mass production as $\sim 20$ tons day $^{-1}$ in the Mexico City afternoon boundary layer when using a traditional SOA model. Implementing SOA formation from primary semi-volatile and intermediate volatility species through the volatility basis set formalism (VBS, Robinson et al., 2007; Grieshop et al., 2009) substantially increases the predicted SOA to levels similar to those observed (Dzepina et al., 2009; Hodzic et al., 2010a; Shrivastava et al., 2010). However, substantial uncertainties persist in terms of the identity and sources of the SOA precursors and the mechanism parameters, as well as on the influence of other proposed SOA formation mechanisms (e.g. Hodzic et al., 2010a). In particular, the VBS approach requires adding the emissions of primary organic vapors as they are not included in current inventories. For Mexico City, this missing mass was added to models as 7.5 times the emissions of POA (Dzepina et al., 2009; Tsimpidi et al., 2010; Hodzic et al., 2010a). This emission amount is considerable and highly uncertain although it is the main driver for the predicted SOA mass. In addition, the full VBS approach is computationally very costly, as it requires keeping track of organic vapor and particle-phase species over 9 volatility bins and multiple particle size bins commonly used to represent the aerosol size distribution. A reduced VBS approach has been recently proposed by Shrivastava et al. (2010) which reduces the computational burden of the method while maintaining a link to the originally-proposed parameterization.

In the aerosol field measurement community, the formation of SOA in polluted airmasses has been recently studied and parameterized by considering ratios of $\mathrm{OA}$ to a chemically quasi-inert species such as carbon monoxide (CO), which allows removing the effect of dilution and emissions on timescales of several days (de Gouw et al., 2005; DeCarlo et al., 2010). Indeed, in urban and regional scales, $\mathrm{CO}$ is approximately conserved with regard to $\mathrm{OH}$ oxidation on timescales of hours to several days which are relevant to SOA formation, and its main sources are the combustion from traffic and from biomass burning, and long-range transport. Chemical production of $\mathrm{CO}$ from anthropogenic VOCs makes a very small contribution to polluted airmasses (Griffin et al., 2007). Although production from biogenic VOCs can make a major contribution to background CO levels in biogenically influenced areas (Hudman et al., 2008), this source does not result in narrow plumes with several hundred ppb of $\mathrm{CO}$, where the SOA vs. $\mathrm{CO}$ parameterizations for pollution and biomass burning sources have been derived (e.g. Kleinman et al., 2008; DeCarlo et al., 2010).
To remove the influence of background (long range transport) $\mathrm{CO}$, it is common to consider $\triangle \mathrm{CO}$ as the measured $\mathrm{CO}$ minus the $\mathrm{CO}$ background. As $\mathrm{CO}$ and POA have similar or generally collocated emission sources, their ratio $(\mathrm{POA} / \Delta \mathrm{CO})$ is relatively constant when averaged over a source region, and can be estimated from ambient measurements. The continuing good correlation between $\mathrm{OA}$ and $\mathrm{CO}$ and the large measured increase in $\mathrm{OA} / \Delta \mathrm{CO}$ ratios downwind of urban areas can then be attributed to the rapid growth of secondary organic aerosols due to anthropogenic pollution. de Gouw and Jimenez (2009), DeCarlo et al. (2010), and Cubison et al. (2011) summarize the observed OA/ $\Delta C O$ enhancement ratios from studies at multiple worldwide locations for fresh and aged urban and biomass burning emissions. Urban $\mathrm{POA} / \triangle \mathrm{CO}$ ratios were found to range from 5$12 \mu \mathrm{g} \mathrm{m}^{-3} \mathrm{ppmv}^{-1}$, with the lower values likely to be more correct as the higher values may have some SOA contamination (de Gouw and Jimenez, 2009). Total OA/ $\Delta \mathrm{CO}$ ratios in aged urban air are systematically higher than those measured in the source region by about an order-of-magnitude. Very similar $\mathrm{OA} / \triangle \mathrm{CO}$ evolution and asymptotic levels ranging from $50-110 \mathrm{~g} \mathrm{~m}^{-3} \mathrm{ppmv}^{-1}$ in aged air were found for various polluted locations in the Northeast US, Central Mexico, Tokyo and the Po Valley. In plumes influenced by biomass burning, $\mathrm{POA} / \triangle \mathrm{CO}$ ratios are initially much higher $\left(50-240 \mu \mathrm{g} \mathrm{m}^{-3} \mathrm{ppmv}^{-1}\right)$ than for urban airmasses, and net $\mathrm{OA} / \triangle \mathrm{CO}$ enhancement during aging appears to vary from a small reduction to a gain comparable to the POA emissions (de Gouw and Jimenez, 2009; Yokelson et al., 2009; Cubison et al., 2011). For example in the forest fires that dominated biomass burning impacts in the Mexico City region during the MILAGRO experiment the net $\mathrm{OA} / \Delta \mathrm{CO}$ enhancement seems to be in the same range as for the urban emissions (40-60 $\mu \mathrm{g} \mathrm{m}^{-3} \mathrm{ppmv}^{-1}$, DeCarlo et al., 2010).

As these studies suggest a rather consistent behavior and evolution of the $\mathrm{OA} / \Delta \mathrm{CO}$ ratios in polluted plumes regardless of their geographic location, we investigate in the present study whether a simplified empirical parameterization based on the observed OA vs. $\triangle \mathrm{CO}$ relationship could be used to predict the amount of anthropogenic SOA. Using CO as a proxy is a particularly convenient choice as $\mathrm{CO}$ is typically well reproduced by models, can be measured from satellites, and also has similar or collocated emissions sources as SOA precursors. A similar approach has recently been applied to a global model by Spracklen et al. (2011). By adjusting the strength of the different SOA sources to optimize the agreement between modeled and measured OA and non-fossil carbon, these authors reported that the optimized global SOA budget appears to be dominated by an anthropogenically controlled source, due to both SOA formation from anthropogenic VOCs $\left(\sim 10 \mathrm{Tg} \mathrm{yr}^{-1}\right)$ and a very large contribution $\left(\sim 90 \mathrm{Tg} \mathrm{yr}^{-1}\right)$ from anthropogenic pollution enhancement of SOA from biogenic VOC. However, the Spracklen et al. (2011) study was performed at a very coarse horizontal resolution $\left(2.8^{\circ} \times 2.8^{\circ} \sim 300 \mathrm{~km} \times 300 \mathrm{~km}\right)$, and 
using monthly mean SOA observations, which do not have sufficient detail to resolve polluted urban conditions. Thus there is a need to explore whether the conclusions of that global study hold when evaluated with a regional model at much higher spatial and temporal resolution.

Therefore the goal of the present study is to test and optimize a first order SOA parameterization for anthropogenic pollution based on the observed $\mathrm{SOA} / \triangle \mathrm{CO}$ ratios that best describes the observed OA. We also propose a simple parameterization to estimate the oxygen-to-carbon ratio $(\mathrm{O} / \mathrm{C})$ of $\mathrm{OA}$ in polluted regions. For that purpose the regional chemistry-transport model predictions are evaluated against ground and aircraft data from Mexico City during the major MILAGRO 2006 field project. Although this type of empirical parameterization does not have mechanistic detail, or allow predicting some OA properties such as volatility, being able to estimate SOA with a simple scheme is of great interest for global and climate modeling studies that need to evaluate the transport and radiative impact of aerosols. The optimized parameterization is compared with SOA predictions from the more complex volatility basis set approach. Finally, we also test two simplified parameterizations of biogenic SOA enhancement due to anthropogenic pollution.

\section{Modeling approach}

\subsection{General model description}

For this study, the mesoscale chemical transport model CHIMERE was run from 15 to 31 March 2006 over the Mexico City region at both regional $(35 \mathrm{~km} \times 35 \mathrm{~km})$ and urban $(5 \mathrm{~km} \times 5 \mathrm{~km})$ grid scales using the same configuration and the same forcing (i.e. meteorology, emissions, boundary and initial conditions) as described by Hodzic et al. (2009, 2010a, b). Here we provide a brief summary of sources and processes that influence the levels of organic aerosols, and introduce the simplified SOA modeling approach that was applied in the present study. The terminology used in the paper is summarized in Table 1.

The CHIMERE model simulates the emissions of primary $\mathrm{OA}$, the chemistry and gas/aerosol partitioning of secondary organic species and their gaseous precursors, in addition to their transport, boundary layer mixing, and dry and wet deposition processes. Similar to Hodzic et al. (2009, 2010a, b), primary gaseous and aerosol species are emitted from (i) anthropogenic sources as reported by the 2002 official Mexico City Metropolitan Area emission inventory (CAM, 2004) and the National Emissions Inventory (NEI) of 1999 emissions outside of the city (http://mexiconei.blogspot.com/), (ii) biomass burning emissions as estimated from satellite data by Wiedinmyer et al. (2006), and (iii) biogenic VOC emissions calculated online using the MEGAN model (Guenther et al., 2006).
As CO is an important model component for this study, it is important to evaluate whether the model can reproduce the measured CO levels. Hodzic et al. (2009) have shown that $\mathrm{CO}$ inside Mexico City is generally well captured by the model in comparison to the RAMA monitoring stations, suggesting that the Mexico City emissions are reasonable with the regard to $\mathrm{CO}$, which is consistent with several previous evaluations of the $\mathrm{CO}$ emissions inventory (Zavala et al., 2006; Molina et al., 2007, 2010). However, comparison with aircraft measurements (Hodzic et al., 2010a) suggested the model tendency to underpredict regional CO levels. This underprediction may be due to too low emissions in urban areas outside Mexico City, which are taken from the Mexico NEI inventory. $\mathrm{CO}$ boundary conditions from the monthly climatology of the LMDZ/INCA global chemistry-transport model could also be too low and contribute somewhat to this gap. However as the population in Mexico City is 20 million, but in other urban areas in Central Mexico is about 10 million, or about $1 / 2$ of the population in Mexico City (Molina et al., 2010), the regional emissions of $\mathrm{CO}$ are expected to be significant. We evaluated these emissions using the measured $\mathrm{CO}$ at the cities of Puebla $\left(19.05^{\circ} \mathrm{N}, 98.2^{\circ} \mathrm{W}\right)$ and Toluca $\left(19.29^{\circ} \mathrm{N}, 99.67^{\circ} \mathrm{W}\right)$, and concluded that the initial model underpredicts the observed $\mathrm{CO}$ levels inside the urban areas by a factor of $\sim 5$ (Fig. S1, Supplement). Therefore the regional NEI emissions of $\mathrm{CO}$ outside of Mexico City have been increased by a factor of 5 . This adjustment results in a small increase the regional background levels with a very minor effect on the Mexico City plume (Fig. S1, see Supplement). The increase in the regional CO levels of $\sim 50 \mathrm{ppb}$ provides a slightly better agreement with the observed $\mathrm{CO}$ levels along the C130 flight track of 29 March 2006 (during a period with very low biomass burning, Aiken et al., 2010).

The SOA treatment in the CHIMERE model that was previously based on Pun et al. (2006) and Hodzic et al. (2009) for anthropogenic and biogenic VOC precursors, and on Hodzic et al. (2010a) for primary organic vapors, has been revised for the purpose of this study. SOA formed from anthropogenic and biomass burning precursors has been replaced by the new empirical approach based on field measurements of SOA/ $\triangle \mathrm{CO}$ ratios. Besides the previous traditional biogenic SOA (BSOA) from $\mathrm{OH}$ oxidation of isoprene and terpene precursors, an alternative parameterization has been included in the model in order to evaluate the differences between current BSOA parameterizations and to account for $\mathrm{NO}_{\mathrm{x}}$-dependent BSOA yields. Anthropogenic and biomass burning POA is modeled as a non-volatile species that can now convert to OOA by heterogeneous ageing in the atmosphere. The details of these parameterizations are discussed in sections below. In this study the model does not account directly for the gas-phase chemistry and partitioning of semi-volatile and intermediate-volatility primary organic vapors described by Hodzic et al. (2010a), rather this process is now lumped in the $\mathrm{SOA} / \triangle \mathrm{CO}$ parameterization and the POA aging. In addition to OA, CHIMERE also 
Table 1. Terminology used for the various types of organic compounds, and for model simulations.

\begin{tabular}{|c|c|}
\hline \multicolumn{2}{|c|}{ Gas-phase organic compounds } \\
\hline VOC & $\begin{array}{l}\text { Volatile Organic Compounds: gas-phase organic species of relatively high } \\
\text { volatility (e.g. toluene, isoprene, terpenes). }\end{array}$ \\
\hline $\operatorname{VOC}_{A}\left(\mathrm{VOC}_{\mathrm{BB}}\right)$ & $\begin{array}{l}\text { Volatile Organic Compounds from anthropogenic (biomass burning) origin: } \\
\text { used here as a lumped surrogate anthropogenic (biomass burning) VOC species } \\
\text { for the empirical SOA treatment, and emitted proportionally to anthropogenic } \\
\text { (biomass burning) CO. }\end{array}$ \\
\hline \multicolumn{2}{|c|}{ Condensed-phase organic species } \\
\hline OA & $\begin{array}{l}\text { Organic Aerosol: includes both primary and secondary fractions. It includes } \\
\text { carbon mass (OC) and also the oxygen, hydrogen, and nitrogen mass. }\end{array}$ \\
\hline POA & $\begin{array}{l}\text { Primary Organic Aerosol: emitted directly into the particle phase. Here it is } \\
\text { treated as a non-volatile species that can however age into SOA after } 2 \text { days of } \\
\text { atmospheric processing }\end{array}$ \\
\hline SOA & Secondary Organic Aerosol (from all sources) \\
\hline ASOA & Secondary Organic Aerosol from anthropogenic sources \\
\hline BBSOA & Secondary Organic Aerosol from biomass burning sources \\
\hline BSOA & Secondary Organic Aerosol from biogenic sources \\
\hline \multicolumn{2}{|c|}{ Model Simulations } \\
\hline OPT & $\begin{array}{l}\text { Model simulation based on the empirical parameterization for } \mathrm{SOA} \text { for- } \\
\text { mation from anthropogenic and biomass burning sources, with } \mathrm{VOC}_{\mathrm{A}} \text { and } \\
\mathrm{VOC}_{\mathrm{BB}} \text { emission rates of } 0.08 \mathrm{~g} \text { perg of } \mathrm{CO} \text {, and a reaction rate with } \mathrm{OH} \text { of } \\
1.25 \times 10^{-11} \mathrm{~cm}^{3} \text { molecules }-1 \mathrm{~s}^{-1} \text {. }\end{array}$ \\
\hline ROB & $\begin{array}{l}\text { Model simulation that includes SOA formation from semi-volatile and interme- } \\
\text { diate volatility primary organic vapors according to the volatility basis set of } \\
\text { Robinson et al. (2007) as reported in Hodzic et al. (2010a). }\end{array}$ \\
\hline ROB-like & $\begin{array}{l}\text { Model simulation based on the empirical parameterization for SOA formation } \\
\text { using } \mathrm{VOC}_{\mathrm{A}} \text { and } \mathrm{VOC}_{\mathrm{BB}} \text { emission rates of } 0.08 \mathrm{~g} \text { per } \mathrm{g} \text { of } \mathrm{CO} \text {, and a reaction } \\
\text { rate with } \mathrm{OH} \text { of } 5 \times 10^{-12} \mathrm{~cm}^{3} \text { molecules } \\
\text { scale as the ROB volatility basis set as shown in Fig. 1a and Table } \mathrm{S} 3 \text { (see } \\
\text { Supplement). }\end{array}$ \\
\hline SPR & $\begin{array}{l}\text { Similar to the OPT model, but with a } \mathrm{VOC}_{\mathrm{A}} \text { emission rate of } 0.20 \mathrm{~g} \text { per } \mathrm{g} \text { of CO } \\
\text { and a rate constant of } 5 \times 10^{-12} \mathrm{~cm}^{3} \text { molecules } \mathrm{s}^{-1} \text { as used in Spracklen et } \\
\text { al. (2011). }\end{array}$ \\
\hline TEST & $\begin{array}{l}\text { Similar to the OPT model, with a pollution enhancement of biogenic SOA, } \\
\text { based on } \mathrm{SO}_{2} \text { and } \mathrm{VOC}_{\mathrm{A}} \text { concentrations. The biogenic SOA formation is } \\
\text { treated using Lane/Tsimpidi } \mathrm{NO}_{\mathrm{x}} \text {-dependent yields. }\end{array}$ \\
\hline \multicolumn{2}{|l|}{ Other notation } \\
\hline VBS & Volatility Basis Set approach \\
\hline AMS & Aerodyne Aerosol Mass Spectrometer \\
\hline OOA & $\begin{array}{l}\text { Oxygenated Organic Aerosols: an OA component identified with Positive Ma- } \\
\text { trix Factorization method, which is characterized by its high oxygen content. It } \\
\text { is generally understood as a surrogate for SOA. }\end{array}$ \\
\hline
\end{tabular}

accounts for wind-blown dust, secondary inorganic species (sulfate, nitrate and ammonium), particulate water, and other primary anthropogenic particles. The size distribution of all species is represented using a sectional approach with 8 size bins ( $40 \mathrm{~nm}$ to 10 microns in physical diameter) with internal mixing within each bin. Further information on the model formulation and related publications can be found on http://www.lmd.polytechnique.fr/chimere.

\subsection{Alternative $\mathrm{NO}_{\mathrm{x}}$-dependent $\mathrm{SOA}$ formation from biogenic precursors}

A 4-species volatility basis set treatment has been included in order to test the effect of alternative parameterizations for the oxidation by $\mathrm{OH}$ of biogenic VOCs, including the effect of low- and high- $\mathrm{NO}_{\mathrm{x}}$ conditions following Lane et al. (2008). Three categories of biogenic precursors are 
considered including isoprene, terpenes and sesquiterpenes. The stoichiometric mass yields that determine the amount of oxidation products in both low- and high- $\mathrm{NO}_{\mathrm{x}}$ regimes use the updated values from Tsimpidi et al. (2009) as summarized in Table 2, without additional gas-phase "aging" for the oxidized organic vapors as this is not well-supported by the literature (e.g. Dzepina et al., 2011). SOA is formed via both low- and high- $\mathrm{NO}_{\mathrm{x}}$ pathways based on the fraction of organo-peroxy radicals that react with NO (Lane et al., 2008). The four oxidation products are then partitioned to the aerosol phase according to their volatility, using the saturation concentrations of $1,10,100$, and $1000 \mathrm{\mu g} \mathrm{m}^{-3}$ at $300 \mathrm{~K}$, respectively. The enthalpies of vaporization are set to $88 \mathrm{~kJ} \mathrm{~mol}^{-1}$ for all four species. Using a similar $\mathrm{NO}_{\mathrm{x}}$ dependent approach Shrivastava et al. (2010) reported that the biogenic SOA predicted in Mexico City was 4-5 times lower than predicted in our previous studies (Hodzic et al., 2009, 2010a) which used higher yields for isoprene under low- $\mathrm{NO}_{\mathrm{x}}$ conditions based on Henze and Seinfeld (2006) and which showed good correspondence with tracer-derived estimates of biogenic SOA (Hodzic et al., 2009). The sensitivity of the model results to the choice of the biogenic SOA parameterization is discussed in Sect. 3.5.1.

\subsection{Simplified SOA parameterization for anthropogenic and biomass burning sources}

SOA from anthropogenic sources has been parameterized based on the observed behavior of $\mathrm{OA} / \Delta \mathrm{CO}$ ratios vs. photochemical age that were reported in the literature, and in particular for Mexico City (Kleinman et al., 2008; DeCarlo et al., 2010). As SOA is a secondary pollutant (unlike $\triangle \mathrm{CO}$ ) that forms from the oxidation of VOC precursors, SOA cannot be emitted directly proportionally to $\mathrm{CO}$ emissions for the purposes of regional modeling (although some global models do treat SOA in this way for simplicity, which is more reasonable for their large spatial and temporal scales, e.g. Textor et al., 2006). The implementation used here is similar to that of Spracklen et al. (2011). The first step of the approach consists in emitting a VOC precursor surrogate $\left(\mathrm{VOC}_{\mathrm{A}}\right.$ for anthropogenic sources) that will gradually oxidize to form SOA downwind of the source region. The ratio of $\mathrm{VOC}_{\mathrm{A}}$ to anthropogenic $\mathrm{CO}$ emissions is assumed to be equal to the observed ratio in concentrations in very aged air under low biomass-burning conditions: $\operatorname{Emis}\left(\mathrm{VOC}_{\mathrm{A}}\right) / \mathrm{Emis}(\mathrm{CO})=\mathrm{SOA} / \Delta \mathrm{CO}$. The SOA$/ \Delta \mathrm{CO} \mathrm{re}-$ ported in the literature for aged polluted air (and also for Mexico City) range from 40 to $110 \mu \mathrm{g} \mathrm{m}^{-3} \mathrm{ppmv}^{-1}$ at standard temperature and pressure (de Gouw and Jimenez, 2009; DeCarlo et al., 2010) which translates into approximately 0.032 to $0.088 \mathrm{~g} \mathrm{~g}^{-1}$ as summarized in Fig. 1a. We note that ratios for very aged air are very difficult to evaluate with field data, due to the effect of dilution and the difficulty of determining the $\mathrm{CO}$ background when $\triangle \mathrm{CO}$ is small, therefore slightly higher asymptotic ratios are possible. This
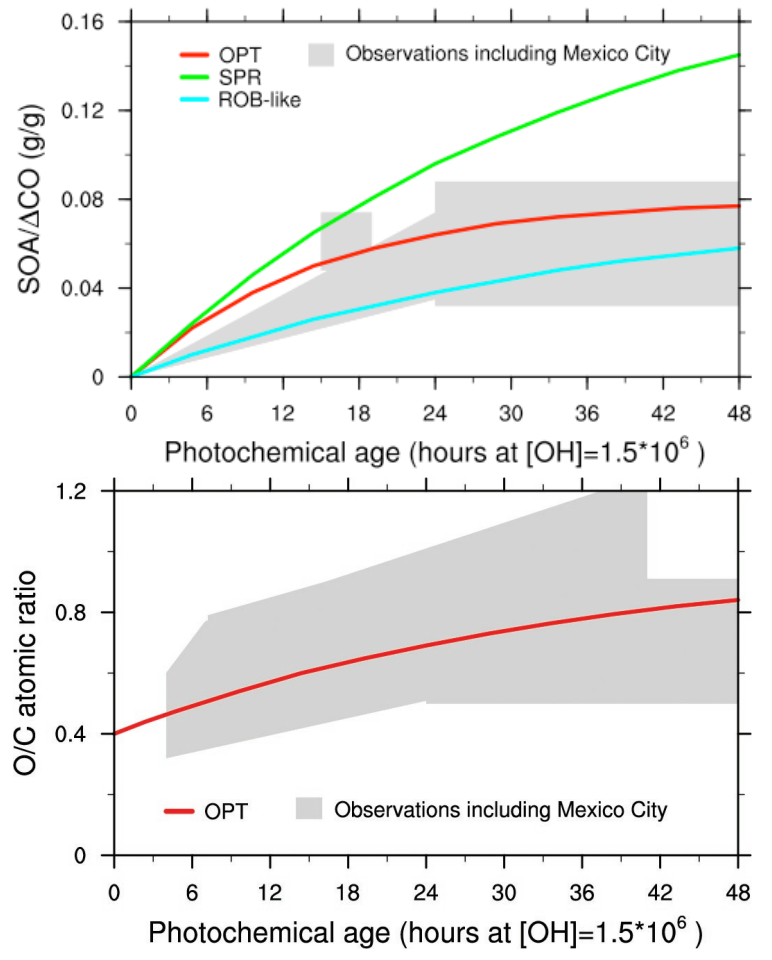

Fig. 1. A schematic representation of the evolution of (a) the $\mathrm{SOA} / \triangle \mathrm{CO}$ and (b) oxygen-to-carbon ratios as a function of photochemical age. For the SOA mass, the observed ratios (gray polygons) are taken from de Gouw and Jimenez (2009) and DeCarlo et al. (2010) for urban airmasses, whereas for the O/C ratios the observed ratios are those summarized in Dzepina et al. (2011). Curves represent the estimated ratios for OPT, SPR and ROB-like simulations for typical daily average $\mathrm{OH}$ concentrations found in Mexico City of $1.5 \times 10^{6}$ molecules $\mathrm{cm}^{-3}$.

parameterization has been derived using data from regions and plumes dominated by anthropogenic pollution. However, since it was derived by fitting ambient observations, it may include a small contribution from biogenic SOA to the regional background. To explore this plausible range, we evaluate the model predictions for several emission factors including $0.025,0.050,0.075,0.100$ and $0.125 \mathrm{~g} \mathrm{~g}^{-1}$. A much higher ratio of $0.20 \mathrm{~g} \mathrm{~g}^{-1}$ was obtained by Spracklen et al. (2011) when optimizing the agreement of their global model with global monthly mean observations, although only $0.02 \mathrm{~g} \mathrm{~g}^{-1}(10 \%)$ were thought to be due to pollution sources and the rest to anthropogenic enhancement of biogenic SOA.

Once the $\mathrm{VOC}_{\mathrm{A}}$ has been emitted, it undergoes oxidation with $\mathrm{OH}$ to produce a single non-volatile product that condenses to the aerosol phase assuming a mass yield of $100 \%: \quad \mathrm{VOC}_{\mathrm{A}}+\mathrm{OH} \rightarrow \mathrm{ASOA}$. The rate constant of this reaction is inversely proportional to the $e$-folding timescale to form pollution SOA and to reach (after several $e$-folding timescales) the asymptotic $\mathrm{SOA} / \Delta \mathrm{CO}$ ratio that was used for the emissions (minus any losses to aerosol deposition). 
Table 2. Reactions leading to the production of SOA and its precursors.

\begin{tabular}{|c|c|c|}
\hline & Reaction & Reaction rate (molecule $\mathrm{cm}^{3} \mathrm{~s}^{-1}$ ) \\
\hline \multicolumn{3}{|c|}{ Production from biogenic precursors at high- $\mathrm{NO}_{\mathrm{x}}$ conditions ${ }^{\mathrm{a}}$} \\
\hline 1 & $\mathrm{ISOP}+\mathrm{OH} \rightarrow 0.001 * \mathrm{BSOA}_{1}+0.023 * \mathrm{BSOA}_{2}+0.015 * \mathrm{BSOA}_{3}$ & $2.5 \times 10^{-11} \exp (408 / T)$ \\
\hline 2 & $\mathrm{TERP}+\mathrm{OH} \rightarrow 0.012 * \mathrm{BSOA}_{1}+0.122 * \mathrm{BSOA}_{2}+0.201 * \mathrm{BSOA}_{3}+0.5 * \mathrm{BSOA}_{4}$ & $1.21 \times 10^{-11} \exp (444 / T)$ \\
\hline 3 & $\mathrm{SESQ}+\mathrm{OH} \rightarrow 0.075 * \mathrm{BSOA}_{1}+0.15 * \mathrm{BSOA}_{2}+0.75 * \mathrm{BSOA}_{3}+0.9 * \mathrm{BSOA}_{4}$ & $1.21 \times 10^{-11} \exp (444 / T)$ \\
\hline \multicolumn{3}{|c|}{ Production from biogenic precursors at low- $\mathrm{NO}_{\mathrm{x}}$ conditions ${ }^{\mathrm{a}}$} \\
\hline 4 & $\mathrm{ISOP}+\mathrm{OH} \rightarrow 0.009 * \mathrm{BSOA}_{1}+0.03 * \mathrm{BSOA}_{2}+0.015 * \mathrm{BSOA}_{3}$ & $2.5 \times 10^{-11} \exp (408 / T)$ \\
\hline 5 & $\mathrm{TERP}+\mathrm{OH} \rightarrow 0.107 * \mathrm{BSOA}_{1}+0.092 * \mathrm{BSOA}_{2}+0.359 * \mathrm{BSOA}_{3}+0.6 * \mathrm{BSOA}_{4}$ & $1.21 \times 10^{-11} \exp (444 / T)$ \\
\hline 6 & $\mathrm{SESQ}+\mathrm{OH} \rightarrow 0.075 * \mathrm{BSOA}_{1}+0.15 * \mathrm{BSOA}_{2}+0.75 * \mathrm{BSOA}_{3}+0.9 * \mathrm{BSOA}_{4}$ & $1.21 \times 10^{-11} \exp (444 / T)$ \\
\hline \multicolumn{3}{|c|}{ Anthropogenically controlled and biomass burning SOA production } \\
\hline 7 & $\mathrm{VOC}_{\mathrm{A}}+\mathrm{OH} \rightarrow \mathrm{ASOA}$ & $1.25 \times 10^{-11^{b}}$ \\
\hline 8 & $\mathrm{VOC}_{\mathrm{BB}}+\mathrm{OH} \rightarrow \mathrm{BBSOA}$ & $1.25 \times 10^{-11}$ \\
\hline \multicolumn{3}{|c|}{ POA ageing } \\
\hline 9 & $\mathrm{POA}_{\mathrm{A}}+\mathrm{OH} \rightarrow \mathrm{OH}+\mathrm{ASOA}$ & $3 \times 10^{-12}$ \\
\hline 10 & $\mathrm{POA}_{\mathrm{BB}}+\mathrm{OH} \rightarrow \mathrm{OH}+\mathrm{BBSOA}$ & $3 \times 10^{-12}$ \\
\hline \multicolumn{3}{|c|}{ Acid-enhanced biogenic SOA production } \\
\hline 11 & $\mathrm{TERP}(\mathrm{SESQ})+\mathrm{SO}_{2} \rightarrow \mathrm{SO}_{2}+0.65 * \mathrm{BSOA}_{\mathrm{EN}}$ & $1 \times 10^{-14^{\mathrm{c}}}$ \\
\hline 12 & $\mathrm{ISOP}+\mathrm{SO}_{2} \rightarrow \mathrm{SO}_{2}+0.65 * \mathrm{BSOA}_{\mathrm{EN}}$ & $1 \times 10^{-14^{\mathrm{c}}}$ \\
\hline \multicolumn{3}{|c|}{ Anthropogenic pollution-enhanced SOA production } \\
\hline 13 & $\mathrm{TERP}(\mathrm{SESQ})+\mathrm{VOC}_{\mathrm{A}} \rightarrow \mathrm{VOC}_{\mathrm{A}}+0.50 * \mathrm{BSOA}_{\mathrm{EN}}$ & $5 \times 10^{-16^{\mathrm{c}}}$ \\
\hline 14 & $\mathrm{ISOP}+\mathrm{VOC}_{\mathrm{A}} \rightarrow \mathrm{VOC}_{\mathrm{A}}+0.50 * \mathrm{BSOA}_{\mathrm{EN}}$ & $5 \times 10^{-16^{\mathrm{c}}}$ \\
\hline
\end{tabular}

a: following Lane et al. (2008) methodology, and using the updated mass yields from Tsimpidi et al. (2009). The four oxidation products i.e. BSOA1, BSOA2, BSOA3, BSAO4, have saturation concentrations of $1,10,100$, and $1000 \mathrm{\mu g} \mathrm{m}^{-3}$ at $300 \mathrm{~K}$, respectively, and the enthalpies of vaporization of $88 \mathrm{~kJ} \mathrm{~mol}^{-1}$ for all four species.

b: this rate is consistent based on field observations reported by de Gouw et al. (2008) and De Carlo et al. (2010). The value indicated here correspond to the OPT simulation. See text for details.

c: these rates are taken from Spracklen et al. (2011), and resulted in a large amount of enhanced biogenic SOA in their global model simulations.

Typically, the timescale is of the order of one day (de Gouw et al., 2005; Brock et al., 2008; Kleinman et al., 2008; DeCarlo et al., 2010). In the Mexico City region the average 24-h OH concentrations are $\sim 1.5 \times 10^{6}$ molecules $\mathrm{cm}^{-3}$ both for the observations (C. Cantrell, NCAR, personal communication, 2008), and for the model (Hodzic et al., 2009, Fig. 9). Given these values, the reaction rate derived by Spracklen et al. (2011) results in a time constant of $\sim 1.5$ days which is somewhat larger than observations. In order to cover a wide range of possible values and assess the sensitivity to this parameter, three rate constants are considered: $\quad k_{1}=5 \times 10^{-12} \mathrm{~cm}^{3}$ molecules ${ }^{-1} \mathrm{~s}^{-1}$, $k_{2}=1 \times 10^{-12} \mathrm{~cm}^{3}$ molecules $\mathrm{s}^{-1} \mathrm{~s}^{-1}$ and $k_{3}=$ $25 \times 10^{-12} \mathrm{~cm}^{3}$ molecules ${ }^{-1} \mathrm{~s}^{-1}$.

In addition, the formation of ASOA from the ageing of primary organic aerosols through the evaporation of POA and the oxidation of its vapors in the gas-phase (Robinson et al., 2007) is represented as a direct oxidation of POA to ASOA assuming the POA half-life time of 2 days. As this ageing is $\mathrm{OH}$-dependent, we introduced this dependence through the following reaction $\mathrm{POA}+\mathrm{OH}->\mathrm{ASOA}$ with $k=$ $3 \times 10^{-12} \mathrm{~cm}^{3}$ molecules ${ }^{-1} \mathrm{~s}^{-1}$. This results in a timescale of $\sim 2.5$ days which is roughly consistent with observations and other model results (Dzepina et al., 2009; Spracklen et al., 2011). The ASOA produced by this pathway conserves the size distribution of its parent POA species. Note that the amount of anthropogenic SOA formed via direct POA oxidation is small, as most of the SOA in the Robinson mechanism is formed by oxidation of gas-phase species co-emitted with the POA.

A similar approach as for anthropogenic SOA is adopted for biomass burning SOA formation. The $\mathrm{VOC}_{\mathrm{BB}} / \mathrm{CO}$ emission ratio and reaction rate for the oxidation of $\mathrm{VOC}_{\mathrm{BB}}$ into BBSOA were varied as described above (together with the parameters for ASOA) in order to determine the set of parameters that reproduces the best the observed OOA values. The ageing of primary organic aerosols emitted by fires is also accounted using same $\mathrm{OH}$-dependent rate discussed above. 


\subsection{Empirical approach for predicting oxygen-to-carbon $(\mathrm{O} / \mathrm{C})$ ratios}

In addition to parameterizing the SOA mass, we have also derived an empirical approach to compute the oxygen-tocarbon ratio for organic aerosols. The measured $\mathrm{O} / \mathrm{C}$ ratio is a good indicator of the level of processing of the organic material. Being able to accurately predict $\mathrm{O} / \mathrm{C}$ ratios in models is of great importance for determining the hygroscopicity of organic particles (Jimenez et al., 2009) and their effects on CCN activation and clouds. As previously, we have parameterized the ageing patterns observed in $\mathrm{O} / \mathrm{C}$ ratio as illustrated in Fig. $1 \mathrm{~b}$ to fit the $\mathrm{O} / \mathrm{C}$ observations reported for Mexico City and its outflow region (Dzepina et al., 2011). Typically, the $\mathrm{O} / \mathrm{C}$ atomic ratios vary from very low $(\sim 0.1)$ for primary emitted organics, to levels close to $0.35-0.4$ in freshly formed SOA, and up to $0.8-1$ for aged air masses that contain more processed organic material. For this purpose the oxygen amount and its increase due to organic aerosol ageing were explicitly modeled in the OPT simulation, adding an additional transported variable into the model. The increase in $\mathrm{O} / \mathrm{C}$ ratios in SOA particles due to ageing of the aerosol was parameterized according to the following equation: $\mathrm{O} / \mathrm{C}=1-0.6 \exp (-A / 1.5)$ where $A$ represents the photochemical age of the airmass in days and 1.5 is the aging time scale for Mexico City conditions. At each model time step, we estimate the photochemical age of the existing aerosol material from the $\mathrm{O} / \mathrm{C}$ ratios, and then further age the $\mathrm{OA}$ for the chemical time step proportionally to the incremental exposure $([\mathrm{OH}] \times$ time step) divided by the reference exposure $\left(1.5\right.$ days $\times 1.5 \times 10^{6}$ molecules $\left.\mathrm{cm}^{-3}\right)$. The O/C ratio for fossil POA is assumed to be equal to 0.1, whereas for the biomass burning value of 0.3 is used (DeCarlo et al., 2008).

\subsection{Anthropogenically-enhanced SOA formation from biogenic precursors}

Similar to Spracklen et al. (2011) we also test several simple mechanisms to test whether a large enhancement of biogenic SOA in presence of anthropogenic pollutants could explain the spatial and temporal patterns of the SOA observed in and around Mexico City. Besides the enhanced oxidant levels due to pollution which are already accounted for by the default model formulation (Hodzic et al., 2009), possible reasons for this enhanced BSOA formation are high aerosol acidity or $\mathrm{NO}_{\mathrm{x}}$ levels (Hoyle et al., 2011; Spracklen et al., 2011). Following Spracklen et al. (2011), an acidenhanced formation of SOA from terpenes and isoprene was represented using $\mathrm{SO}_{2}$ as a surrogate for aerosol acidity (Table 2, Reactions 11-12). In addition a reaction with $\mathrm{VOC}_{\mathrm{A}}$ is used as a surrogate for reactions with anthropogenic pollution species with a lifetime of 1-2 days (including $\mathrm{NO}_{\mathrm{x}}$ ) (Table 2, Reactions 13-14). We note that in Mexico the main sources of $\mathrm{SO}_{2}$ (volcanoes and refineries, DeCarlo et al., 2008) and $\mathrm{VOC}_{\mathrm{A}}$ (urban areas) are not collocated, so these two approaches should produce slightly different spatial patterns.

\subsection{Model application}

First, a set of 15 model simulations was carried out in order to estimate the optimum parameters for the $\mathrm{VOC}_{\mathrm{A}} / \mathrm{CO}$ emission ratios and the rate constant for $\mathrm{VOC}_{\mathrm{A}}$ conversion into ASOA. The 24-30 March time period with low biomass burning influence (Aiken et al., 2010) was chosen to perform this comparison with AMS data. The same set of ground and airborne AMS data was used in this study as described in Hodzic et al. (2010a). Those include the urban T0 site, the suburban T1 site and the regional C130 flight of 29 March. For these comparisons, biogenic SOA formation was represented as in Hodzic et al. (2009, 2010a), because this parameterization was found to produce a reasonable amount of biogenic SOA when compared to biogenic SOA tracers and contemporary carbon data.

Second, the "optimum" simulation (hereafter referred to as OPT) using the optimized emission ratio and rate constant is performed for the 18-30 March time period, for which the first week includes high biomass burning influence (Aiken et al., 2010). The predicted SOA from the empirical model is compared to the SOA results from our previous study (Hodzic et al., 2010a, referred as ROB) which used a more complex SOA module that accounts for SOA formation from traditional VOC using the 2-product traditional approach and from semi-volatile and intermediate-volatilities species using the approach of Robinson et al. (2007). The predicted SOA from the OPT simulation is also compared to the one modeled using the best-fit parameters from Spracklen et al. (2011), referred as the SPR simulation. For consistency with our previous simulations (ROB), the biogenic SOA is based on Hodzic et al. (2009). The evolution of $\mathrm{O} / \mathrm{C}$ ratio was added to the OPT model and the simulation dedicated to evaluating the predicted $\mathrm{O} / \mathrm{C}$ ratios against observations was performed from 16 to 25 March.

Finally, an additional simulation (TEST) was performed to investigate the $\mathrm{NO}_{\mathrm{x}}$-dependent biogenic SOA formation and its potential enhancement under polluted conditions. Similar to Spracklen et al. (2011), this enhancement was parameterized in two alternative ways as discussed above. The biogenic SOA predicted from this approach was compared to results from our previous work (Hodzic et al., 2009).

It should also be noted that by applying this empirical first order SOA modeling approach the computational cost of the model has significantly decreased compared to the simulations including the volatility basis set (per Robinson et al., 2007) presented in Hodzic et al. (2010a). Indeed, to represent the SOA formation from anthropogenic and biomass burning sources, here we only need to track 2 gas-phase precursor species and 2 product species (ASOA and BBSOA) in each aerosol size bin (total 18 species), whereas the full volatility 
basis set require 18 product species in each aerosol size bin, and an additional 18 gas-phase species (total 162 species). For simulations that also track the oxygen to carbon ratio like in Hodzic et al. (2010a), the difference is even larger i.e. 27 vs. 324 species. Simulations using the simplified basis set formulation of Shrivastava et al. (2010) would require 36 species, or 72 when oxygen to carbon ratio is also tracked.

\section{Results and discussion}

\subsection{Selecting the optimum empirical parameterization for anthropogenic SOA}

Figure 2 summarizes the statistical parameters of the model/measurement comparison for fifteen model runs in simulating SOA at the surface (T0, T1 sites) and in air aloft over the city and its outflow (C130 flight, 29 March), as a response to varying $\mathrm{VOC}_{\mathrm{A}}$ emissions (5 values) and oxidation rate constants ( 3 values). Each simulation was assessed against observed OOA concentrations using root mean square error and correlation coefficients as indicators of model skill, during the low biomass-burning period (24 to 30 March 2006). Emissions of $\mathrm{VOC}_{\mathrm{A}} / \mathrm{CO}$ in the $0.05-0.10 \mathrm{~g} \mathrm{~g}^{-1}$ range and a rate constant at or above $5 \times 10^{-12} \mathrm{~cm}^{3}$ molecules ${ }^{-1} \mathrm{~s}^{-1}$ results generally in lower RMSEs and high correlation coefficients for 2 of the 3 datasets. At the T1 suburban site, however, the amount is matched well by the parameter range just discussed, but the correlation coefficient improves for very low emission and reaction rates. Given the overall results and the relatively wide response surfaces of the statistical parameters, we chose as the optimum combination of parameters for simulating SOA from anthropogenically-dominated sources a $\mathrm{VOC}_{\mathrm{A}} / \mathrm{CO}$ emission ratio of $0.08 \mathrm{~g} \mathrm{~g}^{-1}$ and a rate constant of $1.25 \times 10^{-11} \mathrm{~cm}^{3}$ molecules ${ }^{-1} \mathrm{~s}^{-1}$ ( $e$-folding time constant $\sim 0.6$ days in the typical Mexico City boundary layer). These values are within the range of the measurement-derived amounts and timescales (de Gouw and Jimenez, 2009; DeCarlo et al., 2010) and will be used to represent SOA formation from anthropogenic and biomass burning sources in the rest of the paper (OPT simulation). As the merit functions are relatively broad and there is an anti-correlation between amount and timescale and most response surfaces, slightly different sets of parameters are likely to result in similar fits to the observations. This amount of anthropogenic SOA is not inconsistent with the Mexico City emission inventory. E.g. the ratio of $\mathrm{VOC}_{\mathrm{A}}$ to the traditional anthropogenic SOA precursors (aromatics, large alkanes) is $30 \%$. Note that with this implementation the amount of biomass burning SOA is about twice that observed by DeCarlo et al. (2010), which will compensate the underprediction of some biomass burning events in the model (e.g. Hodzic et al., 2010b).

\subsection{Spatiotemporal patterns and comparison to volatility basis set}

In this section the skill of this empirical SOA module in reproducing the observed SOA levels is assessed against the AMS observations within the city and in the city plume, and against the results of the more complex VBS approach of Robinson et al. (2007) reported in Hodzic et al. (2010a).

\subsubsection{SOA spatial distribution}

Figure 3 compares the predicted spatial distribution of anthropogenic and biomass burning SOA surface concentrations averaged over the 24-30 March period. Similar spatial patterns of SOA concentrations are predicted for the OPT and ROB simulations for the urban and near outflow regions, with highest values associated with the Mexico City basin and downwind locations. The OPT model generates on average about $\sim 6 \mu \mathrm{g} \mathrm{m}^{-3}$ of SOA in downtown Mexico City, and $\sim 3 \mu \mathrm{g} \mathrm{m}^{-3}$ downwind. The OPT simulation predicts $\sim 2 \mu \mathrm{g} \mathrm{m}^{-3}$ higher peak SOA concentration over Mexico City in comparison to the ROB simulation. This difference in averaged concentrations is mainly due to higher early afternoon concentrations predicted by OPT as illustrated in Fig. 4. In the outflow region to the north and south of Mexico City basin, the OPT and ROB simulations show similar SOA concentrations. These similarities are expected as both mechanisms have result in amounts and timescales of the same order, whether SOA is directly generated from the first oxidation of precursor species and then transported as an inert species (OPT), or the SOA is produced from the multigenerational oxidation of organic vapors (ROB). The ageing of POA that is included in the OPT simulation does not increase significantly the SOA concentrations downwind at the considered spatial scale in this study (not shown here), as expected from the low POA/CO emission ratios of anthropogenic sources.

\subsubsection{SOA temporal patterns}

A comparison of the observed and predicted SOA time series at the surface during 18-30 March is shown in Fig. 4ab. The OPT model reproduces fairly well the overall amount of OOA and captures much of its temporal variability. The results are somewhat similar to the ROB predictions with however a more sustained daytime SOA production for OPT. At the urban T0 site (Fig. 4a), the statistical figures-of-merit are comparable for both runs with the model bias (RMSE) of $-1.8 \mu \mathrm{g} \mathrm{m}^{-3}\left(4.7 \mu \mathrm{g} \mathrm{m}^{-3}\right)$ for OPT and $-2.9 \mu \mathrm{g} \mathrm{m}^{-3}\left(5.4 \mu \mathrm{g} \mathrm{m}^{-3}\right)$ for ROB, consistent with the overall agreement within $30 \%$ with the observations. The increase in the correlation coefficient from 0.59 to 0.65 indicates a slightly more consistent temporal correspondence between OPT model and observations compared to ROB. The photochemical production of SOA in the late morning 

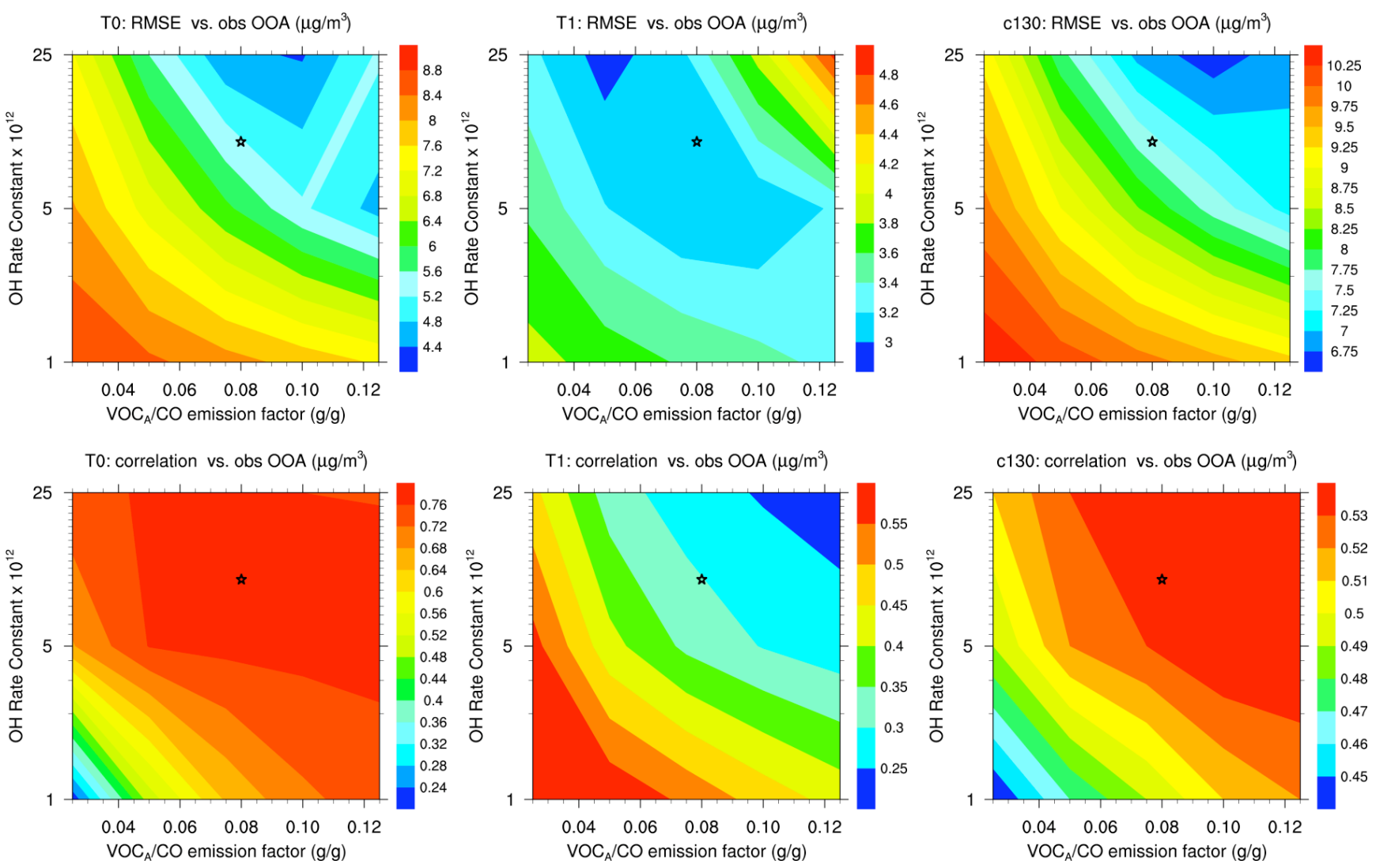

Fig. 2. (Upper panel) Root mean square errors (RMSE) and (Lower panel) correlation coefficients for SOA predictions for 15 model runs as a function of the VOCA surrogate emission factor and its oxidation rate constant. The statistical parameters are calculated for the 24-30 March period, which is characterized by low biomass burning activity. Parameters used for the OPT simulation are also indicated on each plot (star symbol).

( $\sim 99: 00-11: 00 \mathrm{LT}, \sim 8-9 \mu \mathrm{g} \mathrm{m}^{-3}$ ) and the dilution in the growing afternoon boundary layer are remarkably well captured by OPT. The predicted diurnal profile matches both in shape and amounts the OOA observations. The improvements with regard to ROB are mainly seen during the initiation of the photochemistry ( 09:00 LT) and in the late afternoon ( 13:00-16:00 LT). Indeed, the SOA production starts more intensely (additional $3 \mu \mathrm{g} \mathrm{m}^{-3}$ ), and is maintained throughout the afternoon in the OPT model while higher temperatures cause some SOA to evaporate in the ROB model. The temporal pattern of the urban observations in the afternoon is more similar to OPT than ROB, which is consistent with the lower volatility of the observed SOA compared to that produced by ROB (Cappa and Jimenez, 2010; Dzepina et al., 2011; Riipinen et al., 2011; Pierce et al., 2011). Finally, during the nighttime, the OPT predicted background concentrations are lower by $0.5-1 \mu \mathrm{g} \mathrm{m}^{-3}$ than ROB. This is likely caused by enhanced partitioning of semivolatile species to the particle phase in ROB at the lower temperature of this time period, while this effect is not captured by the OPT model formulation. At the T1 suburban site (Fig. 4b), the OPT simulation has $\sim 1 \mu \mathrm{g} \mathrm{m}^{-3}$ lower bias and a slightly higher correlation coefficient than ROB. The contribution of biomass-burning emissions to the predicted SOA stays relatively small during this period at both surface sites (not shown here). The average contribution to the total SOA approaches $0.5 \mu \mathrm{g} \mathrm{m}^{-3}(<10 \%)$, with the strongest influence from 20 to 22 March, consistent with previous observationbased estimates (Aiken et al., 2010).

To study the evolution and growth of organic aerosols aloft and downwind of Mexico City, model predictions are compared in Fig. 4c to the AMS measurements performed onboard the C130 aircraft on 29 March 2006 (DeCarlo et al., 2008). 29 March is characterized by relatively stable atmospheric conditions leading to the accumulation of pollutants within the city basin and its immediate proximity, as well as a very low biomass burning influence. As shown in Fig. 4c the modeled pollution plume peaks near T0 and then extends to the N/NE. The modeled concentrations tend to reproduce the spatial features found in measurements along the aircraft track for CO (Fig. S1, see Supplement) and SOA (Fig. 4c), and also for other organic species as reported by Hodzic et al. (2010a). The results for the empirical OPT model show an average $30 \%$ low bias in comparison with observations, 

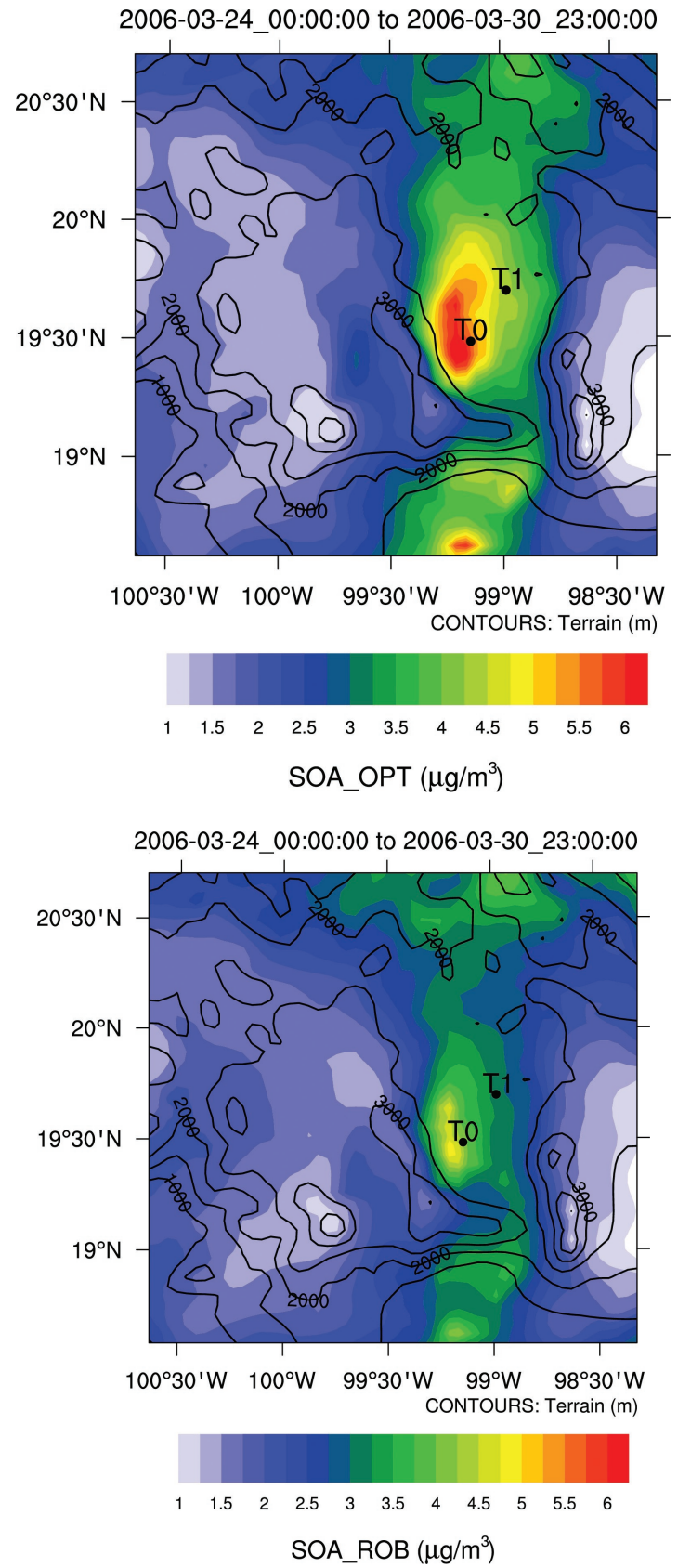

Fig. 3. Spatial distribution of surface SOA concentrations $\left(\mu \mathrm{g} \mathrm{m}^{-3}\right)$ from anthropogenic and biomass burning precursors as predicted for OPT (a) and ROB (b) simulations in the vicinity of Mexico City between 24 and 30 March.

and are again slightly higher $(\sim 30 \%)$ than the predictions of the ROB simulation both within the urban plume and in the downwind region north of the city. Along the first aircraft leg ( 18:30-19:30 UTC) north of the city, the measured SOA levels are reasonably well captured although in this region the SOA displays a strong spatial gradient. Similarly, the high OOA levels found within the urban plume $\left(\sim 15-24 \mu \mathrm{g} \mathrm{m}^{-3}\right)$ are also captured within $30 \%$, which is consistent to the results reported at the T0 downtown site.

\subsubsection{Surrogate parameterization for the volatility basis set}

The similarity with the ROB model results is even more striking when a $\mathrm{VOC}_{\mathrm{A}} / \mathrm{CO}$ emission ratio of $0.08 \mathrm{~g} \mathrm{~g}^{-1}$ and a rate constant of $5 \times 10^{-12} \mathrm{~cm}^{3}$ molecules ${ }^{-1} \mathrm{~s}^{-1}$ are used. This set of parameters results in very similar overall timescales and amount of the ROB model $\left(\sim 100 \mu \mathrm{g} \mathrm{m}^{-3} \mathrm{ppmv}^{-1}\right.$ at standard temperature and pressure, 1.5 days, Dzepina et al., 2011). The results of this sensitivity run ("ROB-like") are shown in Fig. 4. The intensity of the initial photochemical SOA production is comparable in both runs within the city, whereas some differences can be seen later during the day, or at the downwind ground site $\mathrm{T} 1$ due to the higher SOA evaporation in ROB as discussed above. The comparison of the oxidant levels at $\mathrm{T} 1$ (not shown here), indicates that ROB-like simulation has $15 \%$ higher $\mathrm{OH}$ concentrations than ROB. A very good match with the ROB simulation is also found along the $\mathrm{C} 130$ flight track, as the ROB predictions are less affected by the evaporation in the colder upper boundary air. Therefore, out ROB-like model can be used as a surrogate of the ROB model in e.g. global modeling applications where minimizing computational burden is critical.

\subsection{Comparison to results with global model-optimized parameters}

The SOA predictions from the OPT run are also compared with the SPR simulation that uses a larger emission rate for $\mathrm{VOC}_{\mathrm{A}}$ of $0.2 \mathrm{~g} \mathrm{~g}^{-1}$ of $\mathrm{CO}$ and a 2.5 times slower reaction rate, reported as optimum values by the Spracklen et al. (2011) global model study. Figure 1a and Table S3 (see Supplement) compare the typical timescale for SOA production from these two runs. At the near field $(<12 \mathrm{~h})$ both simulations produce a very similar amount of SOA as the faster time constant is compensating the lower emissions of $\mathrm{VOC}_{\mathrm{A}}$ in the OPT simulation as compared to SPR. Significant differences in the predicted SOA amount start to be seen near and after 1 day of atmospheric processing, with a $50 \%$ larger SOA production for SPR than for OPT. After 2 days, the amount of SOA formed by the SPR model is two times larger than for OPT and asymptotically approaches the factor of 2.5 on the $\mathrm{VOC}_{\mathrm{A}}$ emissions. Figure 4 illustrates the behavior of the two simulations close to the emission sources (with the SOA mass dominated by the first day of processing) at T0, T1, and C130 locations. As expected the SPR produces very similar SOA mass and spatio-temporal patterns as OPT, and $50 \%$ larger than ROB both in the immediate vicinity of sources and at the edge of the city. Also, the SPR model simulates $\sim 15 \%$ lower $\mathrm{OH}$ daily mean concentrations than OPT. These results suggest that the SPR parameters with a $\mathrm{VOC}_{\mathrm{A}} / \mathrm{CO}$ emission ratio 2.5 times higher and a timescale 2.5 times slower than OPT lead to very comparable predictions to the OPT model. Within the domain of the data available here, both simulations are plausible. The data 


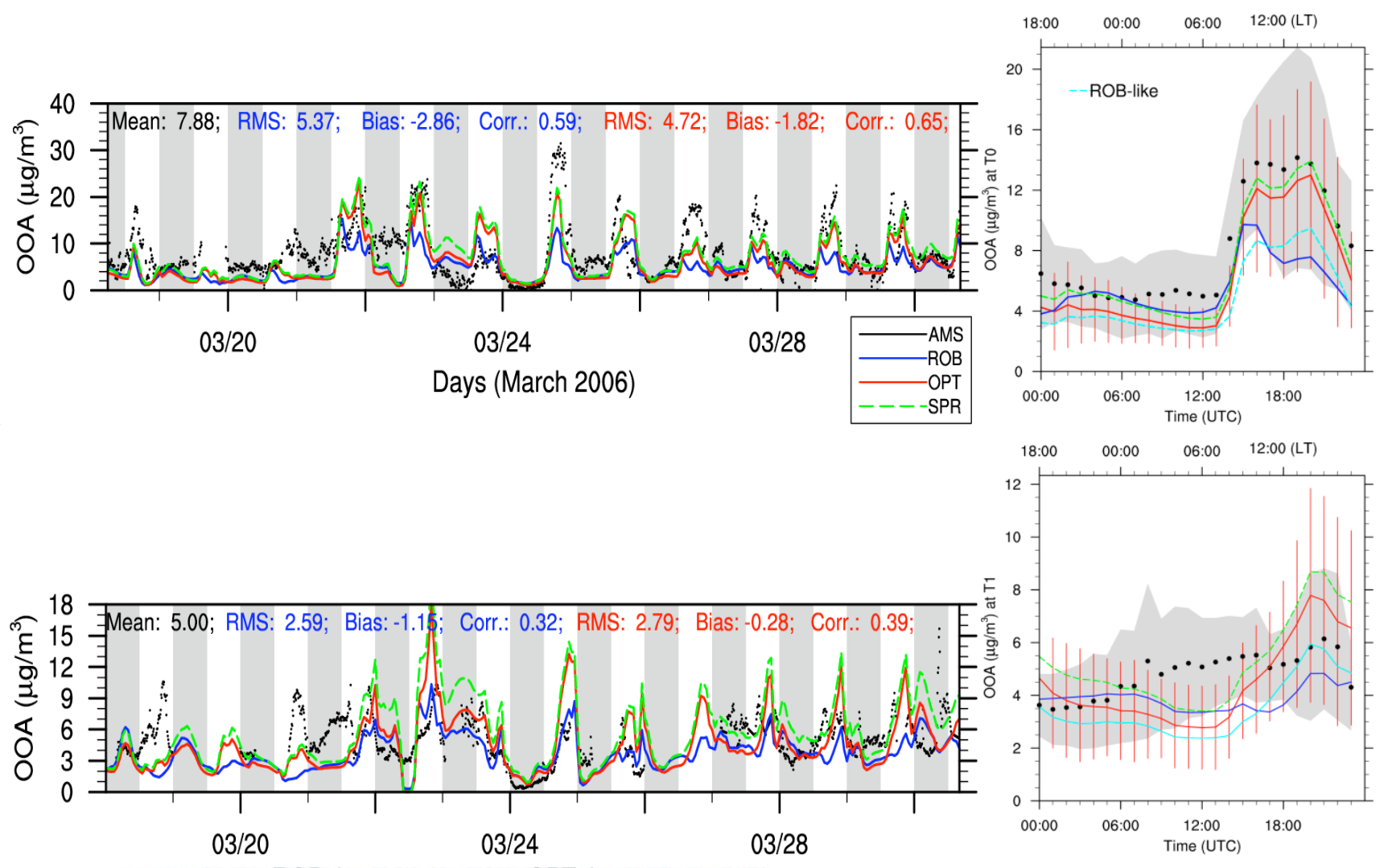

mean=11.24; ROB: $b=-5.14$ r $2=0.54 ;$ OPT: $b=-3.50$ r $2=0.52$
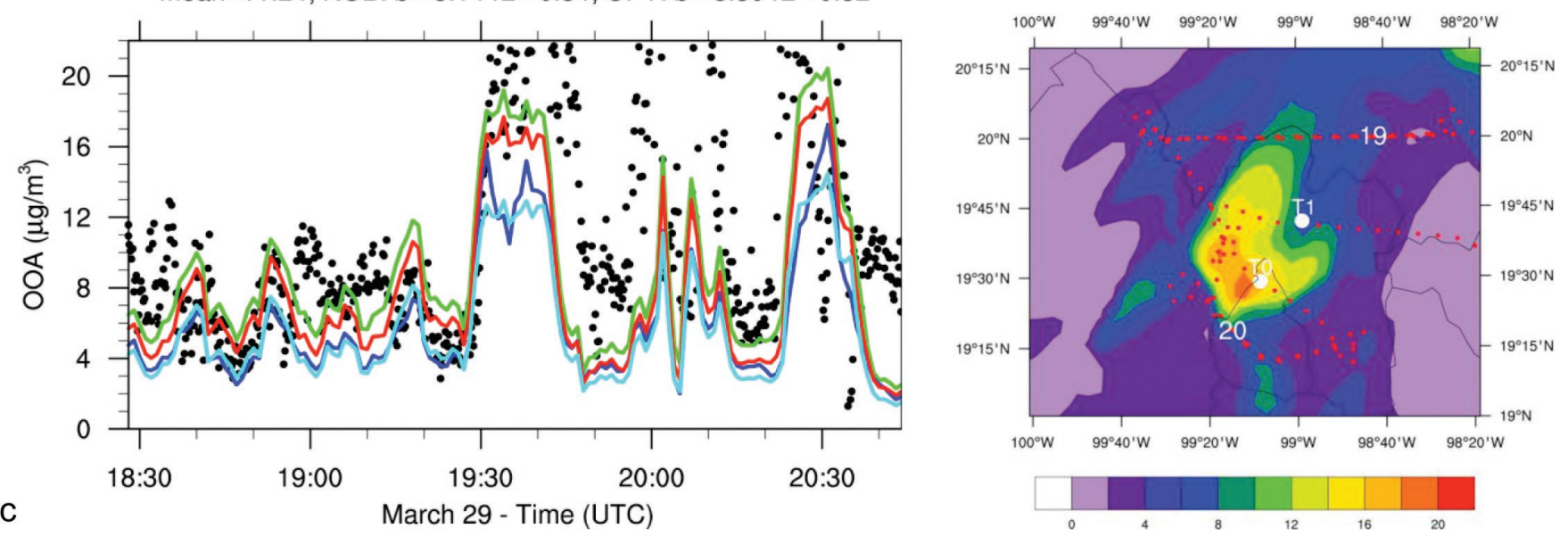

Fig. 4. Observed and predicted concentrations of secondary organic aerosols (OOA or SOA, $\mu \mathrm{g} \mathrm{m}^{-3}$ ) at $\mathrm{T} 0$ (a), $\mathrm{T} 1$ (b), and along the $\mathrm{C} 130$ flight path of 29 March 2006 (c). Plots compare the OPT (red line), ROB (blue line), SPR (green line) and ROB-like (cyan line) model simulations, with the AMS measurements. For surface stations, the diurnal average profiles are also provided in addition to the time series. The variability associated with average observations and OPT model predictions is given in shaded area and red vertical bars, respectively. The C130 flight track for 29 March and the modeled SOA plume extent are also shown.

at longer aging times available for MILAGRO (e.g. DeCarlo et al., 2010) are more uncertain as described above and are also more affected by deposition processes which may lead to an apparent lower ambient ratio. However the timescales of the ambient observations and the lack of very high ambient SOA/ $\triangle \mathrm{CO}$ ratios in ambient air during MILAGRO (other than in BB plumes, DeCarlo et al., 2010) would appear to favor the OPT scheme as more realistic than the SPR one for the MILAGRO conditions. However constraining the SOA source in pollution aged more than one day should be an important priority of future research. 
This study shows however an important qualitative discrepancy with the conclusions of Spracklen et al. (2011) which suggested that $90 \%$ of the predicted SOA mass was of biogenic origin. This would imply that only $1 / 10$ of the simulated SOA mass with the SPR model as discussed above is actually from anthropogenic sources. This ratio appears to be clearly too small to reproduce the measured SOA downtown and in the vicinity of Mexico City (especially during the low biomass burning period) which bears the temporal and spatial signature of the urban area, and thus is almost certainly due mainly to urban sources. The effect of the enhancement of biogenic SOA by anthropogenic pollution is explored further in Sect. 3.5.

\subsection{Evaluation of predicted $\mathrm{O} / \mathrm{C}$ ratios}

Figure 5 compares the simulated $\mathrm{O} / \mathrm{C}$ ratios with estimated values derived from aerosol mass spectrometer measurements at T0. The observed $\mathrm{O} / \mathrm{C}$ ratios range from 0.2 to 0.7 and display a strong diurnal variability with lower values in the morning when the primary emissions from traffic and other sources exert a major influence, and higher values during the daytime $(\sim 12: 00-16: 00 \mathrm{LT})$ when more secondary oxidized matter is being formed by photochemistry. The simulated O/C ratios arising from the OPT simulation show a reasonable agreement with the observed levels both in terms of magnitude and temporal variability. In particular, the ageing of the organic material during the afternoon hours seems to be well captured by this simplified approach as illustrated by the average diurnal profile. The nighttime $\mathrm{O} / \mathrm{C}$ values are often underpredicted in the model, which is consistent with the fact that CHIMERE tends both to overpredict $\mathrm{POA}$ (with low $\mathrm{O} / \mathrm{C}=0.1$ ) during nighttime due to inefficient nighttime boundary layer mixing and underpredict the contribution of biomass burning during the late afternoon or early morning smoldering fires. Both of these issues are discussed in detail in Hodzic et al. (2009).

The result of our simulation is also noticeably closer to the observations than the predictions for the original volatility basis set treatment (Robinson et al., 2007) that had substantially lower O/C levels as discussed in Hodzic et al. (2010) and as illustrated in Fig. 5. Our results are however comparable to predictions of the Grieshop et al. (2009) volatility basis set approach shown in Hodzic et al. (2010) in which $40 \%$ oxygen gain was assumed for each oxidation generation of organic material. The processes leading to this rapid enrichment in oxygen within the first few hours of ageing are currently not understood from a mechanistic point of view.

\subsection{Predicting the enhancement in regional biogenic SOA by pollution in Mexico City}

\subsubsection{Evaluation of the biogenic SOA treatment}

All the simulations described above used the biogenic SOA formulation of Hodzic et al. (2009), which showed good comparison with independent tracer-based estimates, and which does account implicitly for the enhancement in biogenic SOA formation due to the higher oxidants $\left(\mathrm{OH}, \mathrm{O}_{3}\right.$, $\mathrm{NO}_{3}$ ) in polluted air. To evaluate the effect of an alternative biogenic SOA parameterization, within the context of current uncertainties in this area, the $\mathrm{NO}_{\mathrm{x}}$-dependent 4-product biogenic SOA formation has been included in this study following the methodology of Lane et al. (2008) and the updated yields from Tsimpidi et al. (2010). Figure 6 shows the predicted diurnal profiles for biogenic SOA at T0 and T1 during the 24-30 March period. The predicted mass resulting from this new treatment varies between 0.2 and $0.3 \mu \mathrm{g} \mathrm{m}^{-3}$ at both ground sites, as well as downwind of the city along the C130 flight track. These results are consistent with values reported by Shrivastava et al. (2010), which were based on the same approach.

Figure 6 also shows a large gap (i.e. factor of 4 ) between biogenic SOA predictions obtained by the Lane/Tsimpidi method, and those obtained using the approach in Hodzic et al. (2009). The differences arise mainly from the differences in the effective aerosol yields. For instance for isoprene, the Lane/Tsimpidi results in yields at $298 \mathrm{~K}$ and low $\mathrm{NO}_{\mathrm{x}}$ which are $0.7 \%$ and $2.5 \%$ at $\mathrm{OA}$ concentrations of 1 and $10 \mu \mathrm{g} \mathrm{m}^{-3}$, respectively, while the Hodzic et al. (2009) approach produces yields of $2 \%$ and $4.6 \%$ at those concentrations ( $\sim 2-3$ times higher). The difference is even larger for high $\mathrm{NO}_{\mathrm{x}}$ conditions and low organic mass ( $\sim 7$ times). The observed differences are in the range of values reported by Carlton et al. (2010) for different published SOA estimates over the continental US. Their study summarizes that using a 4-product approach for isoprene SOA based on the high- $\mathrm{NO}_{\mathrm{x}}$ experiments of Pandis et al. (1991), Lane and Pandis (2007) found that summertime isoprene SOA contributes $7 \%$ of predicted OA. However, when using the 2-product parameterization of Henze and Seinfeld (2006) based on the low$\mathrm{NO}_{\mathrm{x}}$ experiments of Kroll et al. (2006), Zhang et al. (2007) showed that taking into account the isoprene SOA formation increases simulated surface organic aerosol concentrations by $65 \%$. Clearly these very large uncertainties need to be the focus of future research.

\subsubsection{Assessing the impact of anthropogenic pollutants on biogenic SOA formation}

Figures 6 and 7 show the results of implementing the two simplified mechanisms for pollution-enhancement of biogenic SOA formation. Note that both mechanisms are implemented simultaneously to each other, and to the 

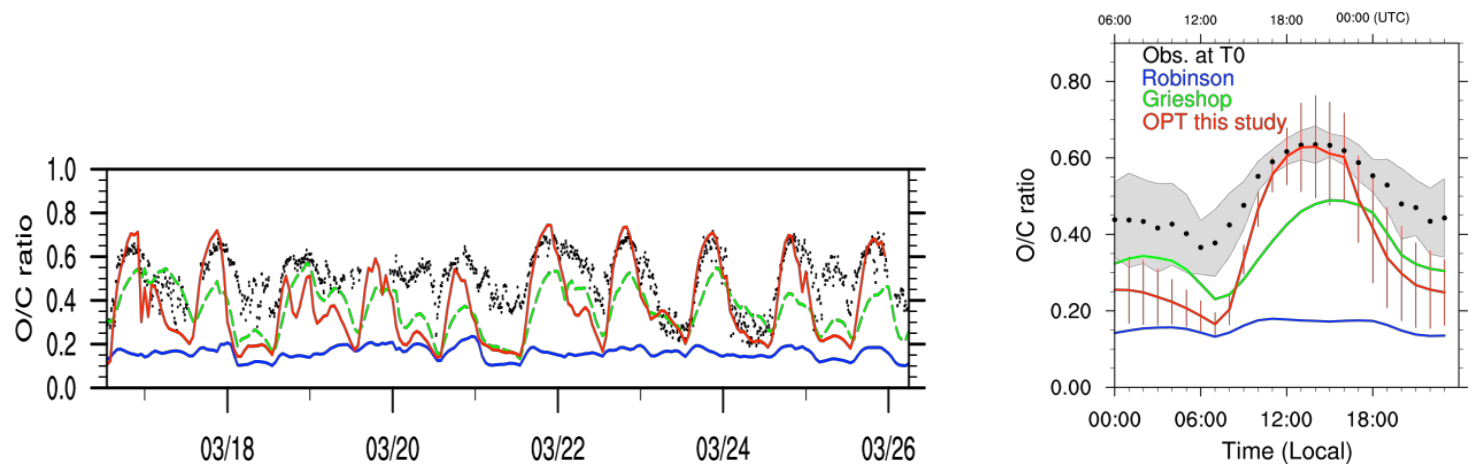

Fig. 5. Time series and associated diurnal profiles of $\mathrm{O} / \mathrm{C}$ ratios as derived from the aerosol mass spectrometer measurement in downtown Mexico City (T0) and as predicted by the first order parameterization derived in this study for the OPT simulation from 16 to 25 March 2006. The results corresponding to the volatility basis set and already reported by Hodzic et al. (2010) are also plotted for reference (i.e. using parameterizations of Robinson et al., 2007 in blue and Grieshop et al., 2009 in green). The gray shaded areas and the red vertical bars indicate the variability associated with the observations and the OPT model respectively.

$\mathrm{NO}_{\mathrm{x}}$-dependent Lane/Tsimpidi approach discussed above. The enhancement of BSOA due to the isoprene and terpene surrogate reaction with $\mathrm{VOC}_{\mathrm{A}}$ is close to $0.1 \mu \mathrm{g} \mathrm{m}{ }^{-3}$ at both ground sites, and to $0.1-0.5$ aloft the city. A much larger enhancement is found for reactions involving $\mathrm{SO}_{2}$, with the total increase of about $2 \mu \mathrm{g} \mathrm{m}^{-3}$ at the surface and up to 4 $5 \mu \mathrm{g} \mathrm{m}^{-3}$ aloft and downwind of the city. This potential enhancement in biogenic SOA formation represents more than a factor of 10 increase as compared to the original BSOA formulation, or a factor of 2 increase with respect to results from Hodzic et al. (2009). However, the absolute amounts formed in our simulations are less robust quantities as they are conditioned by the reaction rates chosen to parameterize the enhancements, which were taken from the global study of Spracklen et al. (2011) and were selected to result in substantial global SOA production.

More importantly, the difference in the spatiotemporal patterns between the enhanced BSOA concentrations and the observed OOA is a more robust indication that the anthropogenically enhanced BSOA does not dominate the SOA production in the vicinity of Mexico City. For instance in Fig. 6c, the $\mathrm{C} 130$ observations show a clear contrast between lower regional OOA levels $\left(\sim 8-10 \mu \mathrm{g} \mathrm{m}^{-3}\right)$ and 3 times larger OOA peaks over the city. This contrast is not captured by the pollution-enhanced BSOA formation as the predicted BSOA levels are similar or larger downwind than within the city. The partitioning of biogenic SOA to the aerosol is somewhat increased due to the presence of ASOA within the city, but this effect is small according to the model.

Figure 7 shows the average spatial distribution for the $\mathrm{NO}_{\mathrm{x}}$-dependent biogenic SOA produced from $\mathrm{OH}$ oxidation of precursors, and the biogenic SOA produced by $\mathrm{VOC}_{\mathrm{A}^{-}}$and $\mathrm{SO}_{2}$ - surrogate enhancements. BSOA displays higher concentrations south and southwest of Mexico City, and is likely originated from emissions on the coastal mountains where isoprene and other biogenic precursors are most abundant (Hodzic et al., 2009). The strongest enhancement in BSOA in our modified model occurs due to presence of $\mathrm{SO}_{2}$, mainly south of the city where the biogenics are at their highest levels, with values exceeding $4 \mu \mathrm{g} \mathrm{m}^{-3}$. Somewhat lower values are found in the city boundary layer $\left(\sim 1-2 \mu \mathrm{g} \mathrm{m}^{-3}\right)$, and to the north and northeast of the city $\left(\sim 2-2.5 \mu \mathrm{g} \mathrm{m}^{-3}\right)$. The BSOA enhancement resulting from the surrogate $\mathrm{VOC}_{\mathrm{A}}-$ enhanced reaction is more limited in terms of average values, and it peaks south of Mexico City. The potential impact of anthropogenic pollution on the BSOA formation with our TEST mechanisms appears to be of a regional scale and to spread well beyond the city limits, producing a very different spatial pattern than the anthropogenic SOA (Fig. 3).

We recognize that the enhancement mechanisms applied here based on Spracklen et al. (2011) are a rather simplified representation of the anthropogenic influence in biogenic SOA formation. However, these same mechanisms result in large OA production when implemented in a global model (Spracklen et al., 2011), and for that reason it was of interest to test their effects in the Mexico City region. Our results indicate that pollution-enhancement of biogenic SOA is unlikely to play a major role in the elevated OA in the Mexico City region due to the physical separation of the pollution and biogenic source regions. However biogenic SOA likely plays a role in the regional background OA, consistent with previous studies (Hodzic et al., 2009) and a quantitative analysis of fossil vs. non-fossil carbon in this region (Hodzic et al., 2010b). Future studies should address the question of anthropogenic enhancement of biogenic SOA using regional models and observations in regions where pollution and biogenic sources are in close proximity, and testing more detailed parameterizations e.g. by directly accounting for particle acidity effects. 

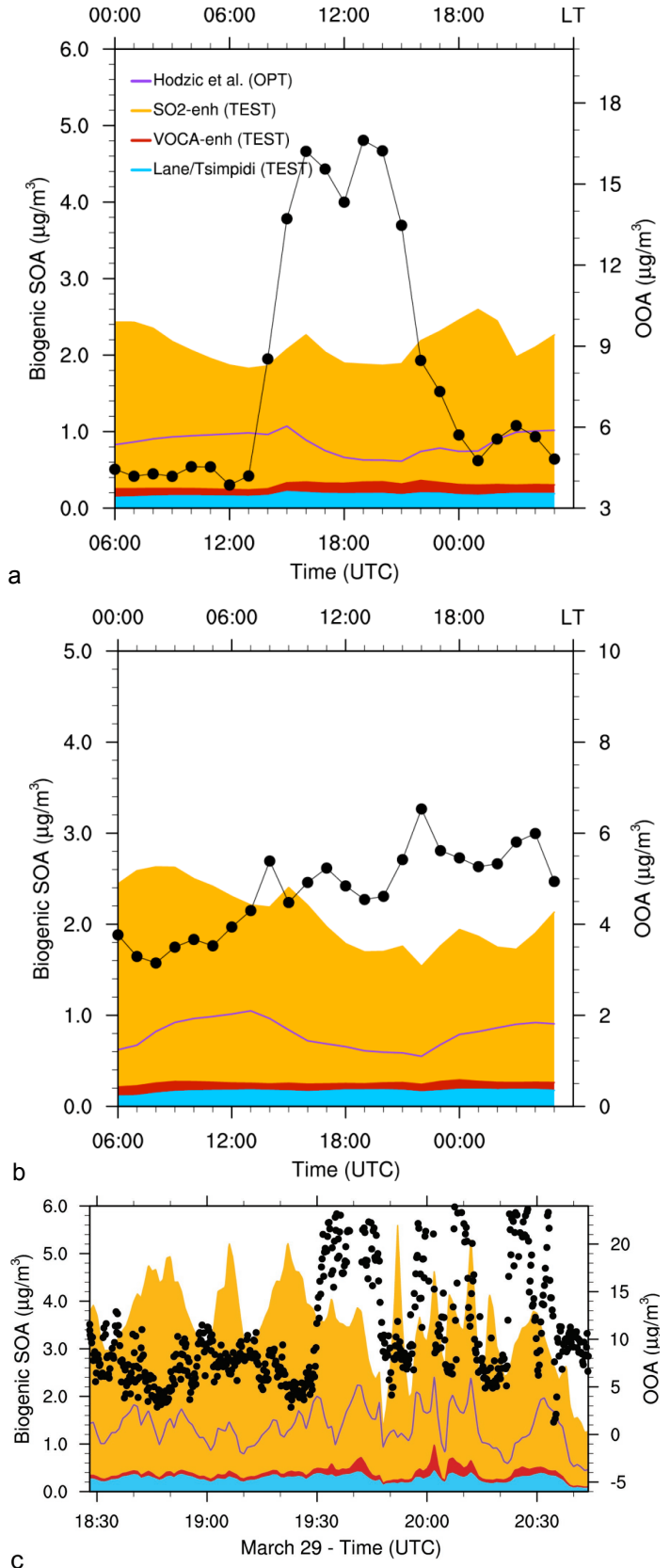

Fig. 6. Average diurnal profiles of submicron secondary organic aerosols (OOA or SOA, $\mu \mathrm{g} \mathrm{m}^{-3}$ ) from biogenic origin as predicted during the 24-30 March comparison period at (a) T0, (b) T1, and (c) time series along the C130 flight track of 29 March 2006. Black dots represent the AMS measured OOA levels (given on the rightside Y-axis). Filled areas represent the BSOA formed from biogenic VOCs according to $\mathrm{NO}_{\mathrm{x}}$-dependent Lane/Tsimpidi yields (blue), from terpenes and isoprene in presence of $\mathrm{VOC}_{\mathrm{A}}$-enhanced reactions (red), and $\mathrm{SO}_{2}$-enhanced reactions (orange). The purple line represents BSOA levels as calculated by the OPT run and using low- $\mathrm{NO}_{\mathrm{x}}$ yields for isoprene based on Henze and Seinfeld (2006).

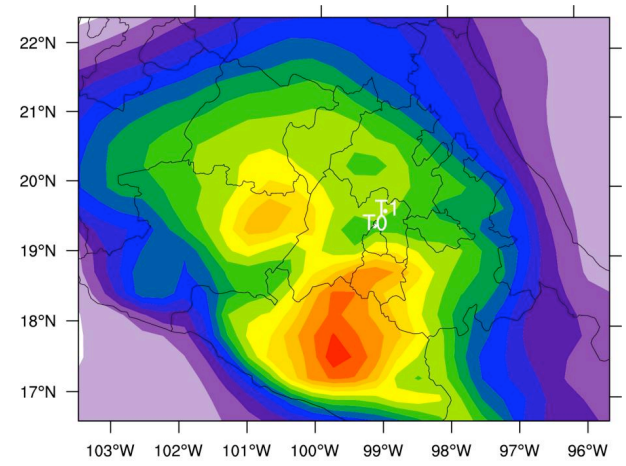

a
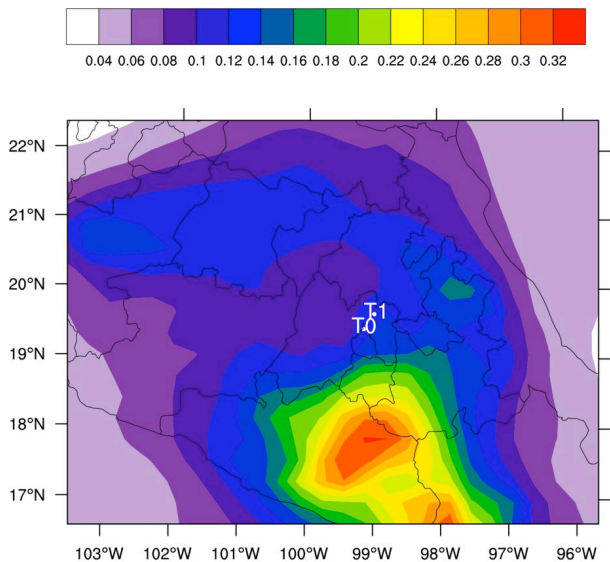

b

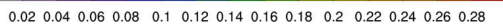

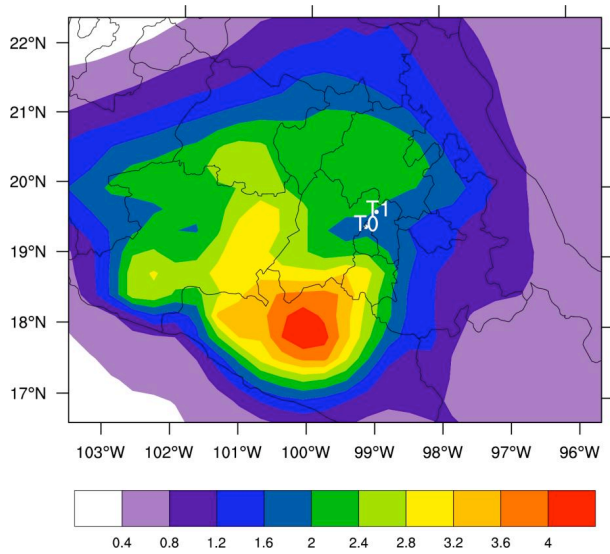

Fig. 7. (a) Spatial distribution of biogenic SOA concentrations $\left(\mu \mathrm{g} \mathrm{m}^{-3}\right)$ as predicted from isoprene and terpenes oxidation following Lane/Tsimpidi $\mathrm{NO}_{\mathrm{x}}$-dependent yields (within the OPT simulation) in the vicinity of Mexico City between 24 and 30 March. The BSOA enhancement due to anthropogenically-enhanced reactions involving biogenic precursors is quantified for (b) $\mathrm{VOC}_{\mathrm{A}}$ and (c) $\mathrm{SO}_{2}$ surrogate reactions. The biogenic $\mathrm{SOA}$ concentrations are vertically averaged from the surface up to $4 \mathrm{~km}$ altitude, and the results are taken from the coarse scale model (at $36 \mathrm{~km}$ horizontal resolution). Note the different color-scales in the three graphs. 


\section{Conclusions}

In this study, we have used a regional chemistry-transport model and highly time-resolved AMS measurements in the Mexico City metropolitan area to derive and test an empirical SOA parameterization for anthropogenic and biomass burning sources based on the measured ratio of organic aerosols to $\mathrm{CO}$ in aged airmasses and suitable for use in global and climate models. The main findings of the study are:

i. We have determined a set of parameters i.e. the emission factor of $0.08 \mathrm{~g}$ per $\mathrm{g}$ of $\mathrm{CO}$ for the emission surrogate, and a rate constant of $1.25 \times 10^{-11} \mathrm{~cm}^{3}$ molecule $^{-1} \mathrm{~s}^{-1}$ for its oxidation with $\mathrm{OH}$, that captures the observed SOA mass within $30 \%$ in the urban area, and downwind. The predicted SOA is mainly anthropogenic as the contribution from biomass burning is less than $10 \%$. Our results also suggest in the source region, somewhat higher (lower) emissions coupled with slower (faster) timescales could also fit the data.

ii. We have shown that using a much larger emission factor of $0.20 \mathrm{~g}$ per $\mathrm{g}$ of $\mathrm{CO}$ and a slower rate constant of $5 \times 10^{-12} \mathrm{~cm}^{3}$ molecule ${ }^{-1} \mathrm{~s}^{-1}$ as advised by the recent global model study by Spracklen et al. (2011) leads to somewhat larger SOA production $(\sim 10-30 \%)$ in the near field. This difference is expected to reach a factor of two after two days of atmospheric processing (aged airmasses). These very high SOA amounts appear inconsistent with the far field data for MILAGRO, although the constraints are weaker and more research is needed in the far field from pollution sources to constrain the total net SOA production amount.

iii. We have shown that our empirical approach can be used as a surrogate for a more complex volatility basis set SOA approach of Robinson et al. (2007) in e.g. global modeling applications where minimizing computational burden is critical. The SOA amount and temporal evolution predicted using the emission factor of $0.08 \mathrm{~g}$ perg of $\mathrm{CO}$ and the rate constant of $5 \times 10^{-12} \mathrm{~cm}^{3}$ molecule ${ }^{-1} \mathrm{~s}^{-1}$ are nearly identical to the results obtained by Hodzic et al. (2010a) for the full volatility basis set of Robinson et al. (2007) or the reduced version of Shrivastava et al. (2010).

iv. Besides the reduced computational cost, the advantage of the present approach is that it is based on the observed SOA levels and processing time scales. Unlike Robinson et al., or Shrivastava et al., approaches, our study does not introduce additional assumptions on the emissions of primary organic vapors, which are currently highly uncertain and not measured. In addition, this method can also be applied in regions where the emissions of SOA precursors are not available e.g. regions in India and China undergoing rapid economic development. v. We have also demonstrated that the evolution of oxygen-to-carbon ratios can be parameterized in a simple way, and used to predict the oxidation state of the organic material in this region. The $\mathrm{O} / \mathrm{C}$ ratios and temporal evolution predicted using the simplified approach are in a slightly better agreement with observations than the results obtained by Hodzic et al. (2010a) for the full volatility basis set of Grieshop et al. (2009) that was assuming a $40 \%$ oxygen gain upon every oxidation of organic vapors.

vi. We have also examined whether the potential enhancement of biogenic SOA production under polluted conditions may explain the observed spatio-temporal patterns and levels of SOA in and around Mexico City. As parameterized here the $\mathrm{SO}_{2}$-enhanced $\mathrm{BSOA}$ production is substantial. However this enhancement alone could not explain the spatio-temporal patterns of observed SOA in and around Mexico City, although it could contribute to the regional background concentrations. Our result does not imply that these interactions are not important in other regions or at the global scale, but that their relative impact is limited in this particular megacity where $\mathrm{OA}$ is dominated by anthropogenic and biomass burning sources.

\section{Supplementary material related to this \\ article is available online at: http://www.geosci-model-dev.net/4/901/2011/ gmd-4-901-2011-supplement.pdf.}

Acknowledgements. This research has been supported by the National Center for Atmospheric Research which is operated by the University Corporation for Atmospheric Research on behalf of the National Science Foundation, and by grants NOAA NA08OAR4310565, DOE (BER, ASR program) DEFG0208ER64627, and NSF ATM-0919189.

Edited by: O. Boucher

\section{References}

Aiken, A. C., de Foy, B., Wiedinmyer, C., DeCarlo, P. F., Ulbrich, I. M., Wehrli, M. N., Szidat, S., Prevot, A. S. H., Noda, J., Wacker, L., Volkamer, R., Fortner, E., Wang, J., Laskin, A., Shutthanandan, V., Zheng, J., Zhang, R., Paredes-Miranda, G., Arnott, W. P., Molina, L. T., Sosa, G., Querol, X., and Jimenez, J. L.: Mexico city aerosol analysis during MILAGRO using high resolution aerosol mass spectrometry at the urban supersite (T0) - Part 2: Analysis of the biomass burning contribution and the non-fossil carbon fraction, Atmos. Chem. Phys., 10, 5315-5341, doi:10.5194/acp-10-5315-2010, 2010.

Brock, C. A., Sullivan, A. P., Peltier, R. E., Weber, R. J., Wollny, A., Gouw, J. A., Middlebrook, A. M., Atlas, E. L., Stohl, A., Trainer, M. K., Cooper, O. R., Fehsenfeld, F. C., Frost, G. J., Holloway, 
J. S., Hubler, G., Neuman, J. A., Ryerson, T. B., Warneke, C., and Wilson, J. C, Sources of particulate matter in the northeastern United States in summer: 2. Evolution of chemical and microphysical properties, J. Geophys. Res.-Atmos., 113, D08302, doi:10.1029/2007JD009241, 2008.

CAM (Comision Ambiental Metropolitana): Inventario de emisiones 2002 de la zona metropolitana del valle de Mexico, Mexico, 2004.

Cappa, C. D. and Jimenez, J. L.: Quantitative estimates of the volatility of ambient organic aerosol, Atmos. Chem. Phys., 10, 5409-5424, doi:10.5194/acp-10-5409-2010, 2010.

Carlton, A. G., Pinder, R. W., and Bhave, P. V.: To what extent can biogenic SOA be controlled?, Environ. Sci. Technol., 44, 33763380, 2010.

Cubison, M. J., Ortega, A. M., Hayes, P. L., Farmer, D. K., Day, D., Lechner, M. J., Brune, W. H., Apel, E., Diskin, G. S., Fisher, J. A., Fuelberg, H. E., Hecobian, A., Knapp, D. J., Mikoviny, T., Riemer, D., Sachse, G. W., Sessions, W., Weber, R. J., Weinheimer, A. J., Wisthaler, A., and Jimenez, J. L.: Effects of aging on organic aerosol from open biomass burning smoke in aircraft and lab studies, Atmos. Chem. Phys. Discuss., 11, 12103-12140, doi:10.5194/acpd-11-12103-2011, 2011.

DeCarlo, P. F., Dunlea, E. J., Kimmel, J. R., Aiken, A. C., Sueper, D., Crounse, J., Wennberg, P. O., Emmons, L., Shinozuka, Y., Clarke, A., Zhou, J., Tomlinson, J., Collins, D. R., Knapp, D., Weinheimer, A. J., Montzka, D. D., Campos, T., and Jimenez, J. L.: Fast airborne aerosol size and chemistry measurements above Mexico City and Central Mexico during the MILAGRO campaign, Atmos. Chem. Phys., 8, 4027-4048, doi:10.5194/acp8-4027-2008, 2008.

DeCarlo, P. F., Ulbrich, I. M., Crounse, J., de Foy, B., Dunlea, E. J., Aiken, A. C., Knapp, D., Weinheimer, A. J., Campos, T., Wennberg, P. O., and Jimenez, J. L.: Investigation of the sources and processing of organic aerosol over the Central Mexican Plateau from aircraft measurements during MILAGRO, Atmos. Chem. Phys., 10, 5257-5280, doi:10.5194/acp-10-52572010, 2010.

de Gouw, J. and Jimenez, J. L.: Organic aerosols in the earth's atmosphere, Environ. Sci. Technol., 43, 7614-7618, 2009.

de Gouw, J. A., Middlebrook, A. M., Warneke, C., Goldan, P. D., Kuster, W. C., Roberts, J. M., Fehsenfeld, F. C., Worsnop, D. R., Canagaratna, M. R., Pszenny, A. A. P., Keene, W. C., Marchewka, M., Bertman, S. B., and Bates, T. S.: Budget of organic carbon in a polluted atmosphere: Results from the New England air quality study in 2002, J. Geophys. Res., 110, D16305, doi:10.1029/2004JD005623, 2005.

Dzepina, K., Volkamer, R. M., Madronich, S., Tulet, P., Ulbrich, I. M., Zhang, Q., Cappa, C. D., Ziemann, P. J., and Jimenez, J. L.: Evaluation of recently-proposed secondary organic aerosol models for a case study in Mexico City, Atmos. Chem. Phys., 9, 5681-5709, doi:10.5194/acp-9-5681-2009, 2009.

Dzepina, K., Cappa, C. D., Volkamer, R. M., Madronich, S., DeCarlo, P. F., Zaveri, R. A., and Jimenez, J. L.: Modeling the multiday evolution and aging of secondary organic aerosol during MILAGRO 2006, Environ. Sci. Technol., 45, 3496-3503, doi:10.1021/es103186, 2011.

Grieshop, A. P., Logue, J. M., Donahue, N. M., and Robinson, A. L.: Laboratory investigation of photochemical oxidation of organic aerosol from wood fires 1: measurement and simulation of organic aerosol evolution, Atmos. Chem. Phys., 9, 1263-1277, doi:10.5194/acp-9-1263-2009, 2009.

Griffin, R. J., Chen, J. J., Carmody, K., Vutukuru, S., and Dabdub, D.: Contribution of gas phase oxidation of volatile organic compounds to atmospheric carbon monoxide levels in two areas of the United States, J. Geophys. Res.-Atmos., 112, D10S17, doi:10.1029/2006JD007602, 2007.

Guenther, A., Karl, T., Harley, P., Wiedinmyer, C., Palmer, P. I., and Geron, C.: Estimates of global terrestrial isoprene emissions using MEGAN (Model of Emissions of Gases and Aerosols from Nature), Atmos. Chem. Phys., 6, 3181-3210, doi:10.5194/acp-63181-2006, 2006.

Hallquist, M., Wenger, J. C., Baltensperger, U., Rudich, Y., Simpson, D., Claeys, M., Dommen, J., Donahue, N. M., George, C., Goldstein, A. H., Hamilton, J. F., Herrmann, H., Hoffmann, T., Iinuma, Y., Jang, M., Jenkin, M. E., Jimenez, J. L., Kiendler-Scharr, A., Maenhaut, W., McFiggans, G., Mentel, Th. F., Monod, A., Prévôt, A. S. H., Seinfeld, J. H., Surratt, J. D., Szmigielski, R., and Wildt, J.: The formation, properties and impact of secondary organic aerosol: current and emerging issues, Atmos. Chem. Phys., 9, 5155-5236, doi:10.5194/acp-95155-2009, 2009.

Henze, D. K. and Seinfeld, J. H.: Global secondary organic aerosol from isoprene oxidation, Geophys. Res. Lett., 33, L09812, doi:10.1029/2006GL025976, 2006.

Hodzic, A., Jimenez, J. L., Madronich, S., Canagaratna, M. R., DeCarlo, P. F., Kleinman, L., and Fast, J.: Modeling organic aerosols in a megacity: potential contribution of semi-volatile and intermediate volatility primary organic compounds to secondary organic aerosol formation, Atmos. Chem. Phys., 10, 5491-5514, doi:10.5194/acp-10-5491-2010, 2010a.

Hodzic, A., Jimenez, J. L., Prévôt, A. S. H., Szidat, S., Fast, J. D., and Madronich, S.: Can 3-D models explain the observed fractions of fossil and non-fossil carbon in and near Mexico City?, Atmos. Chem. Phys., 10, 10997-11016, doi:10.5194/acp10-10997-2010, 2010b.

Hodzic, A., Jimenez, J. L., Madronich, S., Aiken, A. C., Bessagnet, B., Curci, G., Fast, J., Lamarque, J.-F., Onasch, T. B., Roux, G., Schauer, J. J., Stone, E. A., and Ulbrich, I. M.: Modeling organic aerosols during MILAGRO: importance of biogenic secondary organic aerosols, Atmos. Chem. Phys., 9, 6949-6981, doi:10.5194/acp-9-6949-2009, 2009.

Hoyle, C. R., Boy, M., Donahue, N. M., Fry, J. L., Glasius, M., Guenther, A., Hallar, A. G., Huff Hartz, K., Petters, M. D., Petäjä, T., Rosenoern, T., and Sullivan, A. P.: A review of the anthropogenic influence on biogenic secondary organic aerosol, Atmos. Chem. Phys., 11, 321-343, doi:10.5194/acp-11-321-2011, 2011.

Hudman, R. C., Murray, L. T., Jacob, D. J., Millet, D. B., Turquety, S., Wu, S., Blake, D. R., Goldstein, A. H., Holloway, J., and Sachse, G. W.: Biogenic versus anthropogenic sources of CO in the United States, Geophys. Res. Lett., 35, L04801, doi:10.1029/2007GL032393, 2008.

Kiehl, J. T.: Twentieth century climate model response and climate sensitivity, Geophys. Res. Lett., 34, L22710, doi:10.1029/2007GL031383, 2007.

Kleinman, L. I., Springston, S. R., Daum, P. H., Lee, Y.-N., Nunnermacker, L. J., Senum, G. I., Wang, J., Weinstein-Lloyd, J., Alexander, M. L., Hubbe, J., Ortega, J., Canagaratna, M. R., 
and Jayne, J.: The time evolution of aerosol composition over the Mexico City plateau, Atmos. Chem. Phys., 8, 1559-1575, doi:10.5194/acp-8-1559-2008, 2008.

Kroll, J. H., Ng, N. L., Murphy, S. M., Flagan, R. C., and Seinfeld, J. H.: Secondary organic aerosol formation from isoprene photooxidation, Environ. Sci. Technol., 40, 1869-1877, 2006.

Lane, T. E. and Pandis, S. N.: Predicted secondary organic aerosol concentrations from the oxidation of isoprene in the Eastern United States, Environ. Sci. Technol., 41, 3984-3990, 2007.

Lane, T. E., Donahue, N. M., and Pandis, S. N.: Effect of $\mathrm{NO}_{\mathrm{x}}$ on secondary organic aerosol concentrations, Environ. Sci. Technol., 42, 6022-6027, 2008.

Lee-Taylor, J., Madronich, S., Aumont, B., Camredon, M., Hodzic, A., Tyndall, G. S., Apel, E., and Zaveri, R. A.: Explicit modeling of organic chemistry and secondary organic aerosol partitioning for Mexico City and its outflow plume, Atmos. Chem. Phys. Discuss., 11, 17013-17070, doi:10.5194/acpd-11-170132011, 2011.

Molina, L. T., Kolb, C. E., de Foy, B., Lamb, B. K., Brune, W. H., Jimenez, J. L., Ramos-Villegas, R., Sarmiento, J., ParamoFigueroa, V. H., Cardenas, B., Gutierrez-Avedoy, V., and Molina, M. J.: Air quality in North America's most populous city overview of the MCMA-2003 campaign, Atmos. Chem. Phys., 7, 2447-2473, doi:10.5194/acp-7-2447-2007, 2007.

Molina, L. T., Madronich, S., Gaffney, J. S., Apel, E., de Foy, B., Fast, J., Ferrare, R., Herndon, S., Jimenez, J. L., Lamb, B., Osornio-Vargas, A. R., Russell, P., Schauer, J. J., Stevens, P. S., Volkamer, R., and Zavala, M.: An overview of the MILAGRO 2006 Campaign: Mexico City emissions and their transport and transformation, Atmos. Chem. Phys., 10, 8697-8760, doi:10.5194/acp-10-8697-2010, 2010.

Pandis, S. N., Paulson, S. E., Seinfeld, J. H., and Flagan, R. C.: Aerosol formation in the photooxidation of isoprene and betapinene, Atmos. Environ., 25, 997-1008, 1991.

Pierce, J. R., Riipinen, I., Kulmala, M., Ehn, M., Petäjä, T., Junninen, H., Worsnop, D. R., and Donahue, N. M.: Quantification of the volatility of secondary organic compounds in ultrafine particles during nucleation events, Atmos. Chem. Phys., 11, 90199036, doi:10.5194/acp-11-9019-2011, 2011.

Pun, B.: Modeling secondary organic aerosol formation via multiphase partitioning with molecular data. Environ. Sci. Technol., 40, 4722-4731, 2006.

Riipinen, I., Pierce, J. R., Yli-Juuti, T., Nieminen, T., Häkkinen, S., Ehn, M., Junninen, H., Lehtipalo, K., Petäjä, T., Slowik, J., Chang, R., Shantz, N. C., Abbatt, J., Leaitch, W. R., Kerminen, V.-M., Worsnop, D. R., Pandis, S. N., Donahue, N. M., and Kulmala, M.: Organic condensation: a vital link connecting aerosol formation to cloud condensation nuclei $(\mathrm{CCN})$ concentrations, Atmos. Chem. Phys., 11, 3865-3878, doi:10.5194/acp-11-38652011, 2011.

Robinson, A. L., Donahue, N. M., Shrivastava, M. K., Weitkamp, E. A., Sage, A. M., Grieshop, A. P., Lane, T. E., Pandis, S. N., and Pierce, J. R.: Rethinking organic aerosols: Semivolatile emissions and photochemical aging, Science, 315, 1259-1262, 2007.
Shrivastava, M., Fast, J., Easter, R., Gustafson Jr., W. I., Zaveri, R. A., Jimenez, J. L., Saide, P., and Hodzic, A.: Modeling organic aerosols in a megacity: comparison of simple and complex representations of the volatility basis set approach, Atmos. Chem Phys., 11, 6639-6662, doi:10.5194/acp-11-6639-2011, 2011.

Spracklen, D. V., Jimenez, J. L., Carslaw, K. S., Worsnop, D. R., Evans, M. J., Mann, G. W., Zhang, Q., Canagaratna, M. R., Allan, J., Coe, H., McFiggans, G., Rap, A., and Forster, P.: Aerosol mass spectrometer constraint on the global secondary organic aerosol budget, Atmos. Chem. Phys. Discuss., 11, 5699-5755, doi:10.5194/acpd-11-5699-2011, 2011.

Textor, C., Schulz, M., Guibert, S., Kinne, S., Balkanski, Y., Bauer, S., Berntsen, T., Berglen, T., Boucher, O., Chin, M., Dentener, F., Diehl, T., Easter, R., Feichter, H., Fillmore, D., Ghan, S., Ginoux, P., Gong, S., Grini, A., Hendricks, J., Horowitz, L., Huang, P., Isaksen, I., Iversen, I., Kloster, S., Koch, D., Kirkevåg, A., Kristjansson, J. E., Krol, M., Lauer, A., Lamarque, J. F., Liu, X., Montanaro, V., Myhre, G., Penner, J., Pitari, G., Reddy, S., Seland, Ø., Stier, P., Takemura, T., and Tie, X.: Analysis and quantification of the diversities of aerosol life cycles within AeroCom, Atmos. Chem. Phys., 6, 1777-1813, doi:10.5194/acp-61777-2006, 2006.

Tsimpidi, A. P., Karydis, V. A., Zavala, M., Lei, W., Molina, L., Ulbrich, I. M., Jimenez, J. L., and Pandis, S. N.: Evaluation of the volatility basis-set approach for the simulation of organic aerosol formation in the Mexico City metropolitan area, Atmos. Chem. Phys., 10, 525-546, doi:10.5194/acp-10-525-2010, 2010.

Wiedinmyer, C., Quayle, B., Geron, C., Belote, A., McKenzie, D., Zhang, X. Y., O'Neill, S., and Wynne, K. K.: Estimating emissions from fires in North America for air quality modeling, Atmos. Environ., 40, 3419-3432, 2006.

Yokelson, R. J., Crounse, J. D., DeCarlo, P. F., Karl, T., Urbanski, S., Atlas, E., Campos, T., Shinozuka, Y., Kapustin, V., Clarke, A. D., Weinheimer, A., Knapp, D. J., Montzka, D. D., Holloway, J., Weibring, P., Flocke, F., Zheng, W., Toohey, D., Wennberg, P. O., Wiedinmyer, C., Mauldin, L., Fried, A., Richter, D., Walega, J., Jimenez, J. L., Adachi, K., Buseck, P. R., Hall, S. R., and Shetter, R.: Emissions from biomass burning in the Yucatan, Atmos. Chem. Phys., 9, 5785-5812, doi:10.5194/acp-9-5785-2009, 2009.

Zavala, M., Herndon, S. C., Slott, R. S., Dunlea, E. J., Marr, L. C., Shorter, J. H., Zahniser, M., Knighton, W. B., Rogers, T. M., Kolb, C. E., Molina, L. T., and Molina, M. J.: Characterization of on-road vehicle emissions in the Mexico City Metropolitan Area using a mobile laboratory in chase and fleet average measurement modes during the MCMA-2003 field campaign, Atmos. Chem. Phys., 6, 5129-5142, doi:10.5194/acp-6-5129-2006, 2006.

Zhang, Y., Huang, J. P., Henze, D. K., and Seinfeld, J. H.: Role of isoprene in secondary organic aerosol formation on a regional scale, J. Geophys. Res.-Atmos., 112, D20207, doi:10.1029/2007JD008675, 2007. 